\title{
Prevention of Nephropathy by Some Natural Sources of Antioxidants
}

\author{
Azab Elsayed Azab*, Mohamed Omar Albasha, Ata Sedik Ibrahim Elsayed \\ Department of Zoology, Faculty of Science, Alejelat, Zawia University, Alejelat, Libya \\ Email: *azabelsaied@yahoo.com
}

How to cite this paper: Azab, A.E., Albasha, M.O. and Elsayed, A.S.I. (2017) Prevention of Nephropathy by Some Natural Sources of Antioxidants. Yangtze Medicine, $1,235-266$. https://doi.org/10.4236/ym.2017.14023

Received: November 8, 2017

Accepted: December 10, 2017

Published: December 13, 2017

Copyright $\odot 2017$ by authors and Scientific Research Publishing Inc. This work is licensed under the Creative Commons Attribution International License (CC BY 4.0).

http://creativecommons.org/licenses/by/4.0/

\section{(c) (i) Open Access}

\begin{abstract}
Nephrotoxicity is one of the most common kidney problems and occurs when the body is exposed to a drug or toxin. Natural sources of antioxidants may serve as a vital source of potentially useful new compounds for the development of an effective therapy to combat a variety of kidney problems. Natural antioxidants have a variety of biochemical actions such as inhibition of reactive oxygen species production, scavenging of free radicals. The present review aims to summarize the recent articles which studied some of the nephrotoxic agents, and alleviation of nephrotoxicity using of some natural products possessing antioxidant properties. Our review shows the oxidative damage and renal disorders induced in human and experimental animals by nephrotoxic agents such as gentamicin, alcohol, nicotine, adenine, glycerol, ethylene glycol, sodium nitrite, mercuric chloride, $\mathrm{AlCl}_{3}$, lead acetate, carbon tetrachloride $\left(\mathrm{CCl}_{4}\right)$, furosemide, carbendazim, diazinon, heat stress, and $\gamma$-radiation. Also, nephrotic disorders caused in diabetic rats, patients, cirrhotic ascetic patients, and ischemia-reperfusion. Administration of natural sources of antioxidants such as curcumin, garlic, fenugreek, parsley, peppermint, pomegranate, propolis, olive leaves, rosemary, and sesame attenuated both physiological and histopathological alterations induced in the kidney by the nephrotoxic agent and certain diseases. The nephroprotective effect of the former natural sources of antioxidants may be due to the enhancement of antioxidant activity and inhibition of tissue lipid peroxidation. It can be concluded that administration of curcumin, garlic, fenugreek, parsley, peppermint, pomegranate, propolis, olive leaves, rosemary, and sesame showed a remarkable kidney protection against nephrotoxic agents, and diseases induced renal dysfunctions in human and experimental animals. So, the present study recommended that the consumption of these natural sources of antioxidants may be useful for human exposure to nephrotoxic agents and patients who suffer from renal diseases.
\end{abstract}




\section{Keywords}

Nephrotoxicity, Nephroprotective, Curcumin, Fenugreek, Garlic, Parsley, Pomegranate, Propolis, Peppermint, Olive Leaves, Rosemary, Sesame Oil

\section{Introduction}

The kidney is an organ that possesses several biological roles, of which the most important is the homeostatic balance of body fluids by cleaning and secreting metabolites like urea, uric acid, creatinine, and minerals from the blood and excreting the nitrogenous wastes along with water, as urine [1] [2]. It is concerned with many homeostatic mechanisms. It maintains the overall chemical composition of the intracellular environment by regulating the quantity of water, sodium chloride, potassium, phosphate and numerous other substances in the body [3] [4]. It is a common target for toxic xenobiotics due to its capacity to extract and concentrate toxic substances by highly specialized cells and also, due to its large blood flow [5]. Nephrotoxicity is one of the most common kidney problems and occurs when the body is exposed to a drug or toxin [6] [7]. Nephrotoxicity can be authentic as renal disease or dysfunction that arises as an absolute or aberrant after effect of exposure to medicines, and environmental or industrial chemicals. Several factors accept to be articulated which accomplishes the kidney accessible to toxic injury due to indigenous medicines. This includes urine $\mathrm{pH}$, High blood flow rate, high endothelial surface area, high metabolic activity, active uptake by tubular cell and medullary interstitial concentration. The toxins may abuse the tubules directly, or by inducing renal ischemia, hemoglobinuria or myoglobinuria. Continued acknowledgment and acknowledgment of top doses can access the severity of renal failure [8] [9]. The nephrotoxic effect is identified by estimating the biomarkers like serum creatinine and serum urea which are considered reliable markers [2] [10]. A number of potent therapeutic drugs like aminoglycoside antibiotics, NSAID's, chemotherapeutic agents and chemical reagents like ethylene glycol, $\mathrm{CCL}_{4}$, sodium oxalate and heavy metals such as lead, mercury, cadmium, and arsenic can adversely affect the kidney resulting in acute renal failure, chronic interstitial nephritis, and nephritic syndrome, rapid decline in renal function resulting in abnormal retention of serum creatinine and blood urea, which must be excreted [7] [11] [12].

In recent years, attention was directed to the oxidative stress. Oxidative stress is defined as an imbalance between oxidants and antioxidants in favor of the former result in oxidative damage to molecules such as lipids, nucleic acids, proteins and carbohydrates [13]. The antioxidants are important species that possess the ability to protect the body from damage caused by free radicals induced oxidative stress [14]. The body is engaged in a constant battle against damaging chemicals called free radicals, or pro-oxidants to counter the harmful effects of free radicals, the body manufactures antioxidants to chemically neu- 
tralize them. However, the natural antioxidant system may not always be equal to the task [15]. Natural antioxidants strengthen the endogenous antioxidant defenses from reactive oxygen species and restore the optimal balance by neutralizing reactive species [16] [17] [18] [19]. The antioxidant activities of phenolics are related to a number of different mechanisms, such as free radical-scavenging, hydrogen-donation, singlet oxygen quenching, metal ion chelation, and acting as a substrate for radicals such as superoxide and hydroxyl [20].

Plants have been used as medicines for thousands of years all over the world. According to World Health Organization bulletin, an approximate $80 \%$ of the populations of developing countries are still mostly dependent on plant-based medicines for their primary healthcare issues [4] [21]. Plant seeds and herbs are used for treatments of diseases in the folk medicine. Their use was increased in many fields due to their safety and its low side effects as compared with chemical drugs [22]. Herbs are generally considered safe and proved to be effective against various human ailments and their medicinal uses have been gradually increasing in developed countries [23]. Recently, the physiological and histological effects of polyphenol-rich foods, have been receiving much attention as dietary sources of antioxidants that are valuable for human health [24]. Kidney harm is most vital health issues and lots of herbal medicines are involved in case of kidney injury [7]. Herbal medicine has emerged as a skilled approach with sensible values in handling various diseases and developing an affordable phytotherapy to treat severe kidney diseases [7]. Medicinal plants may serve as a vital source of potentially useful new compounds for the development of an effective therapy to combat a variety of kidney problems [12] [25]. The medicinal plants play a prominent role in various diseases. A variety of medicinal plants and plant extracts have been reported for its significant nephroprotective activity in animal models [12]. Many studies showed that the presence of antioxidant compounds in plants conferred them a nephroprotective activity [2] [26] [27]. Natural antioxidants have a variety of biochemical actions such as inhibition of reactive oxygen species production, scavenging of free radicals [2] [28]. The nephroprotective activity is probably due to the presence of Flavanoids in all the few medicinal plants. Extracts of leaves and plants of some medicinal plants have good potentials for use in kidney damage [12]. The nephroprotective activity is in all probably due to the presence of assorted active constituents like alkaloids, benzoquinones, catechols, carotenoids, flavonoids, glycosides, flavonol glycosides, steroid glycosides, glycoalkaloids, terpenoids, monoterpenoids, diterpenoids, triterpene saponins, sterols and polyphenols in all few herbal plants have been reported for its significant nephroprotective activity in animal models. The plant containing these phyto-constituents possesses nephroprotective activity and it has been proven by different animal models which gives many links to develop the future trials. [7].

In the eastern world, treatment with herbs has been used to alleviate disorders related to internal organs for many centuries [29]. The present review aims to 
summarize the recent articles which studied some of the nephrotoxic agents, and alleviation of nephrotoxicity using of some natural products possessing antioxidant properties such as curcumin, garlic, fenugreek, parsley, peppermint, pomegranate, propolis, olive leaves, rosemary, and sesame.

\section{Curcumin (Curcuma longa L.)}

Curcumin (Curcuma longa L.) as one of the naturally occurring dietary substances has been used since ancient times for promoting human health [30]. Curcumin is a major yellow pigment in rhizomes of Curcuma longa Linn which is used widely as a spice and coloring agent in several foods [31]. It represents a class of anti-inflammatory and anti-oxidant reported to be a potent inhibitor of reactive oxygen species (ROS) formation [32].

Azab et al. [5] and Manikandan et al. [33] confirmed that curcumin affords curative role against nephrotoxicity induced gentamicin exposure and reduces gentamicin-induced renal injury. Biswas et al. [34] found that curcumin has antiinflammatory and antioxidant properties with a potent ability to inhibit reactive oxygen species formation. Azab et al. [5] reported that in gentamicin treated Guinea pigs, there were physiological and structural changes in the kidney. The proximal convoluted tubules showed degenerated epithelial lining with disruption of their brush borders and presence of epithelial debris inside their lumens. The renal corpuscle appeared with degeneration of the glomerulus and disrupted Bowman's capsule. The afferent arteriole showed a thickening in its wall and degeneration of endothelial lining with extensive perivascular infiltration of inflammatory cells. Massive interstitial hemorrhage was seen. Also, the serum urea, creatinine, and uric acid were elevated. Co-administration of curcumin significantly improved the structural changes in the kidney and the blood urea, creatinine, and uric acid was significantly declined.

\section{Fenugreek (Trigonella foenumgraecum L.)}

Fenugreek (Trigonella foenumgraecum L.) is an annual herb belonging to Legume family; it is widely grown in India, Egypt, and Middle Eastern countries [35]. It used both in medicine and with food as spice show antioxidant effect through their use in diabetes mellitus due to the presence of different active constituents such as flavonoids, alkaloids, vitamins and amino acids [36]. The yellowish seeds contain compounds with interesting proprieties which explain their use in various ways including medicine, nutrition, beverages, fragrances, cosmetics, smoking, and for other industrial purposes [37]. In fact, toasted and ground fenugreek seed is an essential ingredient of curry powders and is often mixed with breadstuffs [38]. Fenugreek seed is one of the well-known spices in human food which is cultivated worldwide as a semiarid crop. It belongs to the family of Fabaceae. It provides natural food fibers and nutrients required in the human body. It is a rich source of soluble dietary fibers content extract plays a role in its ability to moderate metabolism of glucose in the digestive tract and 
stimulate the appetite as well as modifying food texture. Flavourful and aromatic fenugreek seed is a popular spice and widely used for well recognized medicinal and culinary purposes [39].

Rohini et al. [40] tried to evaluate the diuretic activity of petroleum ether, benzene, ethanol and aqueous extract of Fenugreek seed in Wistar rat, divided into seven groups of six animals in each. The first group received $0.9 \% \mathrm{NaCl}$, the second group received i.p. $10 \mathrm{mg} / \mathrm{kg}$ furosemide, and other groups received i.p 150 and $350 \mathrm{mg} / \mathrm{kg}$ of aqueous extract of Fenugreek seed. Urine volume and $\mathrm{Na}^{+}$, $\mathrm{K}^{+}$and $\mathrm{Cl}^{-}$ion concentrations were estimated. The volume of urine increased significantly at $150 \mathrm{mg} / \mathrm{kg}(\mathrm{p}<0.05)$ and $350 \mathrm{mg} / \mathrm{kg}(\mathrm{p}<0.01)$ and the electrolytes excretion increased in a dose-dependent manner from petroleum ether, benzene chloroform, ethanol and aqueous extracts of Fenugreek seeds respectively. Excretion of sodium, chloride, and potassium was significantly increased in Furosemide group as compared to the control [41]. El-Tawil [42] determine the possible protective effect of fenugreek, against $\gamma$-radiation-induced oxidative stress in kidney tissues of rats. Irradiated rats were the whole body exposed to $3.5 \mathrm{~Gy}$ (Acute dose) $\gamma$-radiations. Fenugreek-treated irradiated rats received $1 \mathrm{~g}$ fenugreek seed powder/kg body weight/day, by gavages, during 7 days before irradiation. Fenugreek treatment has significantly attenuated radiation-induced oxidative stress in kidney tissues, which was substantiated by the significant amelioration of serum creatinine, urea, glucose, and insulin levels. The author concluded that fenugreek would protect from oxidative damage and metabolic disturbances induced by ionizing irradiation. In another clinical trial [43] fenugreek alcoholic extract (1.375 gm of Fenugreek extract dissolved in $7.5 \mathrm{ml}$ distilled water per $12 \mathrm{hrs}$ ) was compared with the equal volume of distilled water given to two groups of five healthy adult male albino rabbits. The duration of the study was 4 weeks through which serum and 24-hr urine samples were analyzed weekly for electrolyte level, osmolality, and $\mathrm{pH}$. Fenugreek caused a significant increase in sodium and potassium excretion with a significant hypocalciuric effect. No significant changes were observed in serum sodium, potassium, chloride, calcium, $\mathrm{pH}$, and osmolality with respect to the control values. She concluded that Fenugreek has a very powerful diuretic effect which is thiazide-like [43]. El-Nawasany et al. [44] reported that herbs such as fenugreek are known to have a diuretic effect in cirrhotic ascitic patients. The safety, tolerability and possible diuretic efficacy of fenugreek were investigated. A study was carried out on 50 patients: Group I: Group II: Basal and final body weight, urine volume $(24 \mathrm{~h}$ ), mean arterial blood pressure, $\mathrm{Na}$ and $\mathrm{K}$ in serum and 24 $\mathrm{h}$ urine were estimated. In Group I: (Furosemide $40 \mathrm{mg}$ tablet and Spironolactone $100 \mathrm{mg}$ tablet once daily for 7 days), the mean loss of body weight was significantly greater. The mean of urine $\mathrm{Na}$ excretion in Group I significantly increased. Mean of serum $\mathrm{Na}$ decreased significantly in Group I, insignificantly increased in Group II: Fenugreek methanol extract $500 \mathrm{mg}$ capsule twice daily for 7 days). 


\section{Garlic (Allium sativum)}

Garlic (Allium sativum) is a bulb-forming herb of Lilliaceae family. It is the oldest cultivated plant and has been used as food, a spice and folklore medicine for over 4000 years [45]. Garlic has many demonstrated medicinal properties such as antiviral, antibacterial, anti-fungal, anti-cancer, reduces cholesterol level and antioxidant capacities. This is due to its medicinally active components such as sulfur-containing compounds (S-alkyl cysteine sulfoxides and the $\gamma$-glutamyl-Salkyl cysteine), high trace minerals, and enzymes [39] [46]. It exhibits medicinal properties including, antibacterial, antioxidant, immunomodulation, antimutagenic, and anticarcinogenic effects [47]. Also, it has been claimed to be effective against a number of diseases [45] [48] [49]. Allium sativum contains several enzymes, at least 33 sulfur compounds, and the minerals calcium, germanium, iron, copper, selenium, magnesium, potassium, and zinc; vitamins A, B1, and C, fiber, and water. It also contains 17 amino acids to be found in garlic: lysine, histidine, arginine, aspartic acid threonine, swine, glutamine, proline, glycine, alanine, cysteine, valine, methionine, isoleucine, leucine, tryptophan and phenylalanine [50] [51]. Garlic mainly contains organosulfur compounds such as allicin, ajoene, diallyl disulphide, diallyltrisulfide, SAC, SAC sulfoxide and flavonoids, phenolics and anthocyanins [45] [52]. It also contains carbohydrates, proteins, fatty acids, glycolipids, phospholipids, fiber, saponins, glycosides lectins, and vitamin B1, B2, B6, C and E [53] [54] [55]. These compounds may be responsible for protecting from tissue damage and various disorders. Aged garlic extract has a high antioxidant content and health protective potential [45]. Organosulfur compounds enhance the activity of glutathione peroxidase and superoxide dismutase; the well documented antioxidant enzymes [56] [57]. Garlic contains certain compounds such as germanium and selenium that play an important role in normalizing the oxygen utilization in the cells [58] [59].

Abirami and Jagadeeswari [60] found that oral administration of mercuric chloride $(100 \mathrm{mg} / \mathrm{kg} / \mathrm{p} .0)$ to albino rats for 30 days resulted in significant increase in LPO Basal level and $\mathrm{LPO} \mathrm{FeSO}_{4}$ induced and the significant decrease in GSH (Glutathione) and Vit C as compared to the normal and control group. Simultaneous administration of garlic along with mercuric chloride produced a pronounced nephroprotective effect against mercuric chloride induced toxicity in rats by restoring the normal levels of biochemical parameters. These may be attributed to the presence of ideally polysulfides that are present in the garlic extract and have been reported to possess antioxidant-like properties [60] [61] [62]. Mirunalini et al. [45] reported that oral supplementation of $1.2 \mathrm{~g} /$ day of garlic cloves to alcoholic patients for 45 days, significantly enhanced the antioxidant status to near normal. Garlic plays a promising role in antioxidant and it can be considered as a potent drug for the treatment of alcoholic disorders. Garlic extract was found to prevent and normalize oxidative stress generated by immobilization stress, which was evident by the reversal of deranged antioxidant enzymatic activities towards their normal values. This is possibly due to the or- 
ganosulfur contents of the garlic like allicin, alliin, and two major organosulfur compounds SAC and S-allyl mercapto cysteine which are potent free radical scavengers [54]. Shiju et al. [63] found that diabetic rats showed significant changes in the urine and serum creatinine, urea, albumin, lipid profile, and glycated hemoglobin compared to that of the control rats. The diabetic rats, which supplemented with aged garlic juice, restored all these biochemical changes. Authors concluded that aged garlic juice has the ability to ameliorate kidney injury in diabetic rats and the renoprotective effect of aged garlic juice may be attributed to its anti-glycation and hypolipidemic activities. Rafieian et al. [64] reported that metformin and garlic juice or their combination has both curative and protective effects against gentamicin nephrotoxicity. Previous studies demonstrated that garlic extract protects against tubular injury by restoring the biochemical alterations and modulation of oxidative stress on the tubules [63] [64] [65] [66] [67].

\section{Parsley (Petroselinum crispum)}

Parsley (Petroselinum crispum), a bright green, a biennial shrub that has been employed in the pharmaceutical, perfume, and cosmetic industries [68], and widely used traditionally as a food additive and herbal remedies for many ailments [69]. It is a member of the Apiaceous family [68]. Parsley extract was reported to produce a diuretic effect and good antioxidant activity [70] [71]. Parsley has anti-inflammatory and probable immune boosting properties make it relevant to the traditional treatment of urinary tract infection, nephritis, cystitis and prevention of renal stones formation. Parsley increases diuresis by inhibiting the $\mathrm{Na}^{+} / \mathrm{K}^{+}$- ATPase pump in the kidney, thereby enhancing sodium and water excretion while increasing potassium re-absorption [71] [72]. In modern medicine, parsley has been exhibited antioxidant, immunosuppressant, cytoprotective, diuretic, antibacterial and antifungal activities [73]. It is one of the most used medicinal plants to treat renal diseases [74], antihyperlipidemic, antihyperglycemic [75], and anti-microbial [76] [77] [78]. Parsley has been used as antiurolithiasis, antiseptic of the urinary tract, diuretic, anti-dote, and anti-inflammatory in folklore and traditional medicines [73]. The active compounds identified in parsley are phenolic compounds and flavonoids particularly apigenin, apiin and 6"-Acetylapiin; essential oil mainly apiol and myristicin; and coumarins [73]. Parsley is a powerhouse of nutrition, rich in tocopherol and vitamin A [75] [79] [80]. It contains starch, vitamins B, C, $\beta$-carotene, and zinc [81]. Also, parsley is a good source of phosphorous, calcium, iron, and antioxidants like luteolin, vitamin A, vitamin C, and zinc [82] [83]. Phytochemically, the leaves, and seeds of Petroselinum crispum has been shown to contain high levels of essential oil known as apiole, while the tender buds contain psoralen and related compounds that can induce photosensitivity and these include xanthotoxin, ficusin, bergapten, majudin, heraclin and antimicrobial furocoumarins namely 8-methoxypsoralen, 5-methoxypsoralen, oxypuecedanin, isopim-pinellin, 6'-acetylopin and 
a new monoterpene glycoside [84] [85] [86]. Parsley exhibits antioxidant and neutralizing properties [80] [87]. Phytochemical screening of parsley has revealed the presence of several classes of flavonoids [88]. Kaempferol, quercetin, apigenin, and luteolin are major flavonoids found in parsley [89]. Kaempferol and quercetin possess a wide range of biochemical and pharmacological effects and have been recommended as chemo preventive agents or nutritional supplements [90] [91]. The predominant mechanism of their biological actions is thought to result from enzyme inhibition, antioxidant activity, and the capacity to scavenge free radicals [90] [92]. Therefore, it is speculated that the healthpromoting effect of parsley may be due to its flavonoid constituents [93].

Parsley is rich in an antioxidant arsenal that includes luteolin, a flavonoid that searches out and eradicates free radicals in the body that cause oxidative stress in cells [80] [94]. Fresh parsley leaf Components scavenges superoxide anion [95], and methanol extracts of parsley scavenge hydroxyl radical [96]. It has been reported that parsley alcoholic extract has a protective effect against toxicity induced by sodium valproate in male rats [97]. Parsley leaves are rich in Apigenin and its glucosidal flavonoids that were found to possess anti-inflammatory especially for renal inflammation; antioxidant and anticancer activities [98] [99]. Parsley extract can be used for kidney and bladder stones because it can be reduced the number of calcium oxalate deposits [100].

Afzal et al. [101] found that a polyherbal formulation containing parsley produced nephroprotective and diuretic effects in rats. Shalaby and Hammoda, [102] found that rats pre-treated orally with parsley extract (100 and $200 \mathrm{mg} / \mathrm{kg}$ ) for 6 weeks and intoxicated with gentamicin $(80 \mathrm{mg} / \mathrm{kg})$ during last 10 days of the experiment showed that a significant decreases in serum urea, creatinine, alkaline phosphatase enzyme, sodium and potassium levels and renal malondialdehyde (MDA), but increased activity of antioxidant enzymes. Also, parsley extract ameliorated renal tubular necrosis and increased urine volume and urinary excretion of sodium and potassium electrolytes, denoting a diuretic effect. Kidneys of rats intoxicated with gentamicin $(80 \mathrm{mg} / \mathrm{kg}$, i.p.) for 10 days revealed marked tubular necrosis. But, kidneys of rats pre-treated with $100 \mathrm{mg} / \mathrm{kg}$ of parsley leaves extract showed mild necrosis in renal tubules with protein casts in their lumen, and kidneys of rats given $200 \mathrm{mg} / \mathrm{kg}$ of parsley extract showed only mild congestion of intertubular blood vessels. A nephroprotective effect may be due to the enhancement of antioxidant activity and inhibition of tissue lipid peroxidation. The nephroprotective effect of parsley was attributed to the antioxidant activity due to its high content of flavonoids [103]. Authors concluded that oral pre-treatment with parsley in gentamicin-nephrotoxic rats caused nephroprotective, diuretic and antioxidant effects as they reversed serum biochemical parameters and mitigated histopathological alterations in kidney induced by gentamicin in rats. These results affirm the traditional use of parsley for the prevention of kidney diseases [102]. Elkhamisy [104] evaluated that the nephroprotective, diuretic and antioxidant effects of parsley leaves extract on gentamicin- 
induced nephrotoxic rats. Gentamicin-induced alterations in serum and urine biochemical parameters decreased antioxidant activity and presence of renal tubular necrosis upon histopathology. Oral pretreatments with parsley leaves extract caused significant decreases in serum levels of urea, creatinine and alkaline phosphatase enzyme, sodium and potassium levels, tissue malondialdehyde and increased activity of antioxidant enzymes. Also, parsley extract increased urinary excretion of $\mathrm{Na}+$ and $\mathrm{K}+$ electrolytes and, urine volume denoting a diuretic activity and mitigated renal tubular necrosis induced by gentamicin. The nephroprotective effect of parsley leaves extract could be attributed to the enhancement of antioxidant enzymes activity and inhibition of lipid peroxidation. These results affirm the traditional use of parsley leaves extract in folk medicine for the prevention of kidney diseases. Also, Mahmoud et al. [105] investigated that the nephroprotective and antioxidant effects of parsley plant as a watery extract of fresh leaves (decoction), fresh leaves, seeds, and seeds oil against gentamicininduced nephrotoxicity in male albino rats. Serum urea, uric acid, and creatinine were reduced significantly in rats received parsley products as compared to gentamicin treated group. Also, intake of parsley leaves decoction $10 \%$ as given orally for 2 months reduced considerably serum creatinine levels [106]. In addition, Khalil et al. [107] confirmed that the protective effect of parsley leaves oils against toxicity induced by $\mathrm{CCL}_{4}$ in experimental rats. Results showed that a-Pinene (26.6\%) and Myristicin (20.3\%) were the main components in Petroselinum crispum oil. Kidney function tests for serum urea nitrogen, creatinine, and uric acid in rats treated with $\mathrm{CCl}_{4}$ were found to be increased. Administration of parsley oils ameliorated the adverse effects and biochemical alterations caused by $\mathrm{CCl}_{4}$. Parsley oils have strong radical scavenging activity and antioxidant activity. Pretreatment with parsley leaves oils showed increased activity of antioxidant enzymes compared to $\mathrm{CCl}_{4}$ treated animals indicating the potentiality of parsley leaves oils to act as an antioxidant by preventing the peroxidative damage caused by $\mathrm{CCl}_{4}$.

\section{Peppermint (Mentha piperita)}

Peppermint (Mentha piperita L., family: Labiatae) is native to the Mediterranean region and nutrient rich. Mentha piperita has carminative and stimulant properties [108] [109]. The main essential oils in peppermint are menthol, menthone and methyl acetate [110]. It used for alleviating flatulence, nausea, and vomiting. It was revealed that peppermint has antioxidant and antiperoxidant properties [109] [111]. It has also been documented for compounds like eugenol, caffeic acid, rosmarinic acid, flavonoids and $\alpha$-tocopherol shaping its antioxidant and antiperoxidant traits [112]. The antioxidant function of peppermint contributes to the prevention and treatment of diseases associated with oxidative stress through scavenging free radicals and neutralizing ferryl ion-induced peroxidation [113]. Peppermint has numerous pharmacological, cosmetic and alimental applications due to its ability to produce terpene and terpenoid compounds. Ba- 
liga and Rao, [114] reported that mint was protected mice against the $\gamma$-radiationinduced sickness and mortality. The radioprotective effects are possibly due to free radical scavenging, antioxidant, metal chelating, anti-inflammatory, antimutagenic, and enhancement of the DNA repair processes. Khalil et al. [107] confirmed that the protective effect of peppermint (Mentha piperita) leaves oils against toxicity induced by $\mathrm{CCl}_{4}$ in experimental rats. Results indicated that the main components in peppermint oil were menthol (35.9\%) and menthone (25.6\%). Serum urea nitrogen, creatinine, and uric acid were found to be increased in rats treated with $\mathrm{CCl}_{4}$. Administration of peppermint oils attenuated the adverse effects and biochemical alterations caused by $\mathrm{CCl}_{4}$. Peppermint, have strong radical scavenging activity and antioxidant activity. Therefore, the results of this study show that peppermint oils led to the protective effect of $\mathrm{CCl}_{4}$ toxicity. Pretreatment with peppermint leaves oils showed increased activity of antioxidant enzymes compared to $\mathrm{CCl}_{4}$ treated animals indicating the potentiality of peppermint leaves oils to act as an antioxidant by preventing the peroxidative damage caused by $\mathrm{CCl}_{4}$.

\section{Pomegranate (Punica granatum L.)}

Pomegranate (Punica granatum L.) is a long-lived and drought-tolerant plant. Arid and semiarid zones are popular for growing pomegranate trees [115]. They are widely cultivated in Iran, India, and the Mediterranean countries such as Turkey, Egypt, Tunisia, Spain, and Morocco [115] [116]. The pomegranate fruit is berry-like with a leathery rind enclosing many seeds surrounded by juicy arils [117]. Pomegranate is an important source of bioactive compounds and has been used for folk medicine for many centuries [118]. This fruit is rich in polyphenols, flavonoids, anthocyanins, punicic acid, ellagitannins, alkaloids, fructose, sucrose, glucose, simple organic acids, and other components and has antiinflammatory [115] [119], and renoprotective [120] [121] [122] [123] properties. Punica granatum can be used in the prevention and treatment of several types of cancer, cardiovascular disease, osteoarthritis, rheumatoid arthritis, and other diseases. Pomegranate can induce its beneficial effects through the influence of its various bioavailable constituents and metabolites on gene expression [115]. Among the antioxidants, punicalagin and ellagic acid have been identified [124]. Punicalagins possess two isomeric forms in pomegranate: $\alpha$ and $\beta$ Punicalagin is an ellagitannin in which the gallagic acid and ellagic acid are linked through a molecule of glucose [125]. Punicalagins and ellagic acid are also responsible for the antioxidant activity and health benefits of pomegranates [126]. Pomegranate contains tannins, phenols, and flavonoids which can directly or indirectly reduce oxidative damage by preventing the excessive generation of free radicals [123] [127].

Ali and Saeed [128] reported that co-treatment of aqueous extract of pomegranate (Punica granatum), attenuated gentamicin-induced renal oxidative damage in rats. The nephroprotective effect of pomegranate extracts may be re- 
lated to different mechanisms. One of these mechanisms is the antioxidant property of pomegranate through scavenger of free radicals released as a consequence of oxidative damage as reported in numerous studies [122] [129]. Aviram et al. [130] and Yasoubi et al. [131] confirmed that the antioxidants, polyphenols are rich in pomegranate and they are more potent, on a molar basis than many other antioxidants, like vitamins $\mathrm{C}$ and $\mathrm{E}$ and coenzyme Q10. Pomegranate is an important source of anthocyanins, hydrolyzable tannins punicalagin and punicalin [132] ellagic and gallic acids [133] and also contains vitamin C [134]. Also, El-Habibi [120] reported that the obtained improvement in the renal physiology of adenine treated rats co-administered with pomegranate juice can be attributed to its high phenolic content and the mechanism of action may be through induction of various antioxidant enzymes and scavenging reactive oxygen species. Furthermore, another mechanism may be through anti-inflammatory and different signaling pathways [120]. In addition, Albasha and Azab, [123] found that In nicotine-treated Guinea pigs, the serum urea, uric acid, creatinine, and potassium ions concentrations were significantly $(\mathrm{p}<0.05)$, increased and sodium ions concentrations were significantly decreased as compared to the control group. Pomegranate juice administration showed a remarkable amelioration of these abnormalities in nicotine-treated male Guinea pigs. These biochemical observations were suggested that pomegranate juice significantly attenuated nephrotoxicity by the way of its antioxidant, radical-scavenging, and antiapoptotic effects.

Singh et al. [122] and Huang et al. [135] reported that the renoprotective effects of pomegranate involve the activation of nitric oxide-dependent and peroxisome proliferator-activated receptor (PPAR- $\gamma$ ) signaling pathway. The protective role of nitric oxide (NO) in different models of renal failure has been documented [136], including glycerol-induced renal failure [137] and nephrolithiasis induced by ethylene glycol [138]. These studies have demonstrated that levels of NO are decreased in glycerol-induced renal failure and different agents have shown to produce renoprotection by increasing the NO production [120].

\section{Propolis}

Propolis is a resinous natural product collected from cracks in the bark of trees and leaf buds which are enriched with salivary enzymes of honey bees. It has more than 180 compounds, including flavonoids, phenolic acids and its esters [19] [20] [139] [140]. Caffeic acid, phenethyl ester, and melatonin are compounds of honeybee propolis, that were recently found to be potent antioxidants and free radical scavengers [19] [141].

Propolis is a wax-like resin produced by honeybees from substances collected from plants, which are mixed with beeswax and other compounds of bee metabolism. It's a mixture of balsams and resins, waxes, essential oils, pollen, and other substances which is used by bees in the construction, repair, and protection of their hives, mainly due to its mechanical properties and antimicrobial ac- 
tivity [142]. Propolis has been used for upper respiratory tract infections, common cold, flu-like infections, as dermatological preparations in wound healing, treatment of burns, acne, herpes simplex and genitals, and neurodermatitis, as mouthwashes and toothpaste to prevent caries and treat gingivitis and stomatitis; in cosmetics; and in health foods and beverages not only to improve health and prevent diseases, but also as an ingredient in many dietary supplements and nutraceuticals [142] [143] [144]. Propolis possesses several biological properties, such as antibacterial, antitumor, anti-inflammatory, local-anesthetic, antioxidant, immuno-stimulating, and nephroprotective [5] [145]-[150]. Park and Kahng [151] found that propolis extract had profound anti-inflammatory effects on both chronic and acute inflammations.

Over 300 chemical components belonging to the flavonoids, terpenes, and phenolics have been identified in propolis [121] [152]. Melatonin and caffeic acid phenethyl ester are compounds of honeybee propolis that were recently found to be potent free radical scavengers and antioxidants [153]. Many flavonoids are known to be antioxidants, and several of these, such as quercetin which has been identified as constituents of propolis has been shown to be inhibitors of low-density lipoprotein oxidation [154].

Salem et al. [155] reported that co-administration of propolis with gentamicin decreased the rise in blood urea and serum creatinine. This effect is probably due to the antioxidant protective effect of propolis which could have accumulated in the cells of the proximal convoluted tubules of the kidney where propolis was reported to be collected and secreted [156]. Osman and Tantaway [157] observed that oral administration of propolis extracts to rabbit significantly protected against histopathological alterations induced by gentamicin. Atta et al. [158] found that propolis ameliorated the renal alterations induced by gentamicin administration as indicated by maintenance of the activity of antioxidant enzymes. Also, Azab et al. [5] reported that treatment of Guinea pigs with 80 $\mathrm{mg} / \mathrm{kg}$ body wt gentamicin for 7 days induced physiological and structural changes in the kidney. The proximal convoluted tubules showed degenerated epithelial lining with disruption of their brush borders and presence of epithelial debris inside their lumens. The renal corpuscle appeared with degeneration of the glomerulus and disrupted Bowman's capsule. The afferent arteriole showed a thickening in its wall and degeneration of endothelial lining with extensive perivascular infiltration of inflammatory cells. Massive interstitial hemorrhage was seen. Also, the serum urea, creatinine, and uric acid were elevated. Co-administration of propolis significantly improved the structural changes in the kidney and the blood urea, creatinine, and uric acid was significantly declined. In addition, Aboulgasem et al. [159] reported that Guinea pigs that received sodium nitrite orally at a dose of $80 \mathrm{mg} / \mathrm{kg}$ body weight, daily for 35 days had significantly, increased the serum urea, uric acid, and creatinine, sodium ion, and potassium ion concentrations. Propolis supplementation showed a remarkable amelioration of these abnormalities in sodium nitrite treated male Guinea pigs. This is perhaps 
due to the antioxidant actions of the propolis extract [5] [159]. Some antioxidant compounds identified in propolis include ferulic acid, quercetin and caffeic acid [160]. The antioxidant activities of phenolics are related to a number of different mechanisms, such as free radical scavenging, hydrogen-donation, singlet oxygen quenching, metal ion chelation, and acting as a substrate for radicals such as superoxide and hydroxyl. A direct relationship has been found between the phenolic content and antioxidant capacity of plants [17]. The antioxidant activities of propolis are related to its ability to scavenge singlet oxygen, superoxide anions, peroxy radicals, hydroxyl radicals and peroxynitrite [161]. The primary mechanism of the effect of propolis may involve the scavenging of free radicals that cause lipid peroxidation. The other mechanism may comprise the inhibition of xanthine oxidase, which is known to cause free radicals to be generated [162].

\section{Olive Tree (Olea europaea)}

The olive tree (Olea europaea), family: Oleaceae, and in particular, its leaves have been used for the treatment of wounds, fever, diabetes, gout, atherosclerosis, and hypertension since ancient times [163]. In the Mediterranean area, olive leaves are one of the by-products of farming of the olive grove; they can be found in high amounts in the olive oil industries and they accumulate during pruning of the olive trees [164]. Olive Leaves have been widely used in traditional remedies in European and Mediterranean countries such as Greece, Spain, Italy, France, Turkey, Israel, Morocco, and Tunisia [165]. Olive leaf contains large amounts of potentially useful phytochemicals, many of the same phenolics as the olive oil but in much higher concentration [166]. Olive leaf contains triterpenes (oleanolic, ursolic, and maslinic acid), flavonoids (luteolin, apigenin, and quercetin), caffeic acid, and tannins [167]. Experimental animal studies on different total olive leaf extract or their constituents have demonstrated hypoglycemic [168], hypotensive [169], nephroprotective [165], antiatherosclerotic [170], antitumor [171] and anti-inflammatory activity [172].

The potential of olive leaf extract in the reduction of the serum levels of glucose, lipids, uric acid, and creatinine was noticed in streptozotocin-induced diabetic rats [173]. The antioxidant activity of phenolic compounds in olive leaf extract could be a result of the presence of hydroxyl groups in their structure such as oleuropein, hydroxytyrosol, and luteolin [174]. Ashour, [175] reported that a significant increases in serum urea, and creatinine levels in $\gamma$-irradiated rats at a dose level of 4 and 6 Gy as compared with corresponding control rats after 2 weeks. Ethanolic extract of olive leaves at a dose of $200 \mathrm{mg} / \mathrm{kg}$ b.w. caused a significant decrease in serum urea, and creatinine levels after 2 weeks of treatment at dose level 4 and 6 Gy, respectively. Zari and Al-Attar, [176] mentioned that carbendazim induced a significant increase in plasma creatinine. Moreover, after one month of carbendazim exposure, there were severe changes in the structures of the kidney. There were several alterations in the structure of kidney, including disarrangement of renal cortex and medulla tissues with severe 
congestion of blood vessels with hemorrhage and abnormal structure of renal corpuscles, which appearing a high degeneration of glomeruli and Bowman's capsules. Pretreatment of carbendazim-exposed rats with olive leaves extract showed marked improvement in both physiological and histopathological alterations. Tavafi et al. [177] recorded that olive leaf extract protects from gentamicininduced nephrotoxicity by enhancing renal glutathione content, antioxidant enzymes activity and inhibition of lipid peroxidation. In addition, Visioli et al. [178] found that olive phenolics increase glutathione levels in healthy volunteers. Also, the effective role of the extracts may partially explain by hypotensive effects of olive leaf extract that make kidney work normally (Nekooeian [179]). Again, the histological findings of almost normal renal histological architecture corroborate the decreased levels of urea and creatinine confirmed protection effects by the extract within the stipulated time interval, especially at the maximum oral dose the extract [180]. Al-Attar and Abu Zeid [181] found that exposure of mice to $6.5 \mathrm{mg} / \mathrm{kg}$ body weight of diazinon for seven weeks resulted in statistical increases in serum alkaline phosphatase activity and creatinine level. Treating diazinon-intoxicated mice with olive leaves extracts significantly attenuated the severe alterations in these biochemical parameters. These results indicated that the extracts of olive leaves can be considered as promising therapeutic agents against nephrotoxicity, and metabolic disorders induced by diazinon and maybe by other toxicants and pathogenic factors. Al-Jubury [182] reported that a significant increase of urea, uric acid and creatinine levels in sera of heatstressed rabbits for 30 days were recorded, while there is an improvement of these three parameters in the animal treated with the dried $(1000 \mathrm{mg} / \mathrm{kg} / \mathrm{b} . \mathrm{w}$. and $2000 \mathrm{mg} / \mathrm{kg} / \mathrm{b} . \mathrm{w}$.) and aqueous extracts of olive leaves $(200 \mathrm{mg} / \mathrm{ml}$ and 400 $\mathrm{mg} / \mathrm{ml}$ ) for 30 days. Rafighdoost et al. [183] reported that serum BUN of ischemiareperfusion (IR) group was significantly increased. The three groups treated with olive leaf extract compared to I/R group could reduce serum BUN, but only group 4 was significantly different from I/R group ( $\mathrm{p}=0.01)$. The BUN level was similar to the control group. In comparison with control group, tubular dilatation and necrosis were significantly increased in I/R group $(\mathrm{p}=0.0)$. Pretreatment with olive leaf extract in the three groups $(25 \mathrm{mg} / \mathrm{kg}, 50 \mathrm{mg} / \mathrm{kg}$ and 100 $\mathrm{mg} / \mathrm{kg}$ ) could reduce significantly tubular necrosis and the intra diameter of proximal tubule with olive leaf extract was similar to intra diameter of the control group. Al-Sowayan and Mousa [165] found that treatment of rats with $\mathrm{CCl}_{4}$ ( $5 \mathrm{ml} / \mathrm{kg}$ body wt., i/p diluted in 9 volumes olive oil) for six weeks significantly increased the level of serum creatinine, urea and significantly reduced the level of uric acid. Histopathological changes including glomerular atrophy, tubular necrosis, necrosis of epithelium, interstitial edema and congestion in capillary loops were observed after $\mathrm{CCl}_{4}$ administration. Treatment with olive leaf extract (50 mg/kg body wt./d or $100 \mathrm{mg} / \mathrm{kg}$ body wt./d) significantly attenuated the biochemical and histopathological alterations induced by $\mathrm{CCl}_{4}$ suggesting that olive leaf extract protected $\mathrm{CCl}_{4}$-induced nephrotoxicity through enhancement 
of renal antioxidant system. Zoair, [184] reported that serum creatinine, urea, and uric acid were significantly elevated in diabetic rats compared with control rats. Treatment of diabetic rats with olive leaf extract returned these parameters towards normal. Jemai et al. [185] reported that in the diabetic rats, kidney sections revealed tubular lesions, fatty infiltration, collapsed or occluded glomerular capillary tufts and a marked reduction in the size of the glomeruli. Furthermore, hemorrhage was clearly observed. Treatment with the antioxidant olive leaf 3 , 4-dihydroxy-phenyl ethanol rich extract markedly reduced these tubular and glomerular lesions.

\section{Rosemary (Rosmarinus officinalis)}

Rosemary (Rosmarinus officinalis) is herb commonly used as a spice and flavoring agents in food processing and is useful in the treatment of many diseases [18] [186] [187]. It is composed of dried leaves and flowers constitutes a particularly interesting source of biologically active phytochemicals as it contains a variety of phenolic compounds including carnosol, carnosic acid, rosmanol, 7-methyl-epirosemanol, isorosmanol, rosmadial and caffeic acid [186] [188]. Rosemary extracts have a high scavenging capacity of different types of reactive oxygen and nitrogen species, mostly free radicals, is thought to be one of the main mechanisms of the antioxidant action exhibited by phenolic phytochemicals [189]. The antioxidant activity of rosemary extract can be attributed mainly to two components, carnosic acid and carnosol [190]. It is useful in prevention of nephrotoxicity [5]. Rosemary is used in folk medicine, as an antispasmodic in renal colic and dysmenorrhea, in relieving respiratory disorders, and to stimulate growth of hair [191]. The aqueous extract of rosemary used as a drug with strong antioxidant properties for eliminating the generated free radicals, reinforce the antioxidant system and prevent oxidative stress [192].

Tavafi and Ahmadvand [193] found that co-treatment of gentamicin and rosemarinic acid significantly decreased serum creatinine and urea and the tubular necrosis. Aqueous extract of rosemary alleviates the toxicity induced by lead on the kidney through stimulation of endogenous antioxidant defense system [194]. Rosemary extract alleviates the nephrotoxicity induced by $\mathrm{CCL}_{4}$ in albino rats [187]. The protective effect of rosemary can be explained that rosemary extract has a high scavenging capacity of different types of reactive oxygen and nitrogen species, mostly free radicals, as thought to be one of the main mechanisms of the antioxidant action exhibited by phenolic phytochemicals [189]. Mannaa et al. [195] reported that renal dysfunctions of $\mathrm{AlCl}_{3}$, as indicated by significant augmentations of serum urea and creatinine levels, can be modified by rosemary supplementation in combination with $\mathrm{AlCl}_{3}$. The rosemary aqueous extract alleviates the toxicity induced by lead on the kidney through stimulation of endogenous antioxidant defense system [196]. Azab et al. [5] reported that in gentamicin treated Guinea pigs, there were physiological and structural changes in the kidney. The proximal convoluted tubules showed degenerated epithelial lining 
with disruption of their brush borders and presence of epithelial debris inside their lumens. The renal corpuscle appeared with degeneration of the glomerulus and disrupted Bowman's capsule. The afferent arteriole showed a thickening in its wall and degeneration of endothelial lining with extensive perivascular infiltration of inflammatory cells. Massive interstitial hemorrhage was seen. Also, the serum urea, creatinine, and uric acid were elevated. Co-administration of rosemary to animals treated with gentamicin regained the structural changes to normal and the blood urea, creatinine, and uric acid were significantly declined. Azab and Albasha, [197] found that the serum urea, creatinine, uric acids and potassium ions concentrations were significantly increased and a significant decrease in serum sodium in Guinea pigs treated with nicotine compared with control animals. Co-administration of nicotine and aqueous extract of rosemary significantly decreased the elevations in the serum urea, creatinine, uric acid and potassium ions concentrations, and induced a significant increase in serum sodium compared with the nicotine-treated group.

The biological activities of rosemary aqueous extracts are mainly attributed to their high concentration of phenolic constituents namely carnosic and rosmarinic acids that are recognized as natural antioxidants [198] [199]. Many studies reported that the preventive effects of rosemary and its extracts are attributed to its antioxidant activity [200]. It is generally assumed that these antioxidant molecules from rosemary may act as free radical scavengers but additionally might play a role by regulating the activity and/or expression of certain enzymatic systems implicated in relevant physiological processes like apoptosis, tumor promotion and intracellular signal transduction [201].

\section{Sesame (Sesamum indicum L.)}

Sesame (Sesamum indicum L.) is one of the most important oilseed crops, having seeds and its edible oil that is highly valued as a traditional healthy food ingredient [202]. Sesame oil comprises approximately $50 \%$ of the seed weight, contains large amounts of natural antioxidants, they also contain a good type of monounsaturated and polyunsaturated fatty acids [203] and vitamin E [204]. It has been found to contain considerable amounts of the sesame lignans: sesamin, episesamin, and sesamolin. The lignans present in sesame oil are thought to be responsible for many of its unique chemical and physiological properties, including its antioxidant properties [204]. It is well known for its multiple health benefits, including hypocholesterolemic, antihypertensive, anti-carcinogenic, anti-aging, immunoregulatory, hypoglycemic, anti-thrombotic, nephroprotective [205], antibacterial, antiviral, anti-fungal and anti-inflammatory [206].

Among the bioactive components in sesame seeds are IP-6 (Phytate; one of the most powerful antioxidants yet found), lignans, pinoresinol, tocopherols, lecithin, myristic acid and linoleate have been identified as the major antioxidants which responsible for the resistance of oxidative deterioration of sesame seeds and oil [207]. The potent antioxidant properties of sesame seed extract mainly 
are attributed to the presence of lignans which are phytoestrogens [208].

Bhuvaneswari and Krishnakumari [209] found that Sesamum indicum ameliorates the renal damage in the diabetic rats after the treatment regimen. Sesamum indicum extract treatment significantly decreased the levels of blood urea and serum uric acid and creatinine in diabetic rats, which could be due to the prevention of protein and nucleic acid degradation. These results may be attributed to the antioxidant nature of vitamin $\mathrm{E}$ present in sesame which acts as a protective agent by breaking the chain reactions of both hydroxyl and peroxyl radicals and by regulating the antioxidative defense enzyme system in the kidney tissues [210]. Azab et al. [205] reported that the serum urea, uric acid, and creatinine parameters were significantly increased in mice received lead acetate (500 $\mathrm{mg} / \mathrm{kg}$ diet) daily for 30 days. Co-administration of sesame oil with lead acetate to mice showed significantly declined in the serum urea, uric acid, and creatinine.

\section{Conclusion}

It can be concluded that administration of curcumin, garlic, fenugreek, parsley, peppermint, pomegranate, propolis, olive leaves, rosemary, and sesame showed a remarkable kidney protection against nephrotoxic agents, and diseases induced renal dysfunctions in human and experimental animals. So, the present study recommended that the consumption of these natural sources of antioxidants may be useful for human exposure to nephrotoxic agents and patients who suffer from renal diseases. Further studies are necessary to elucidate exact mechanism of protection of renal disorders and potential usefulness of these natural sources of antioxidants as a protective agent against nephropathy induced by toxic agents and diseases in clinical trials.

\section{References}

[1] Javaid, R., Aslam, M., Nizami, Q. and Javaid, R. (2012) Role of Antioxidant Herbal Drugs in Renal Disorders: An Overview. Free Radicals and Antioxidants, 2, 1-6. https://doi.org/10.5530/ax.2012.2.2

[2] Cyril, D.G., Landry, K.S., Francois, K.Y.K., Abou, B., Felix, Y.H. and Timothee, O.A. (2016) Evaluation of Nephroprotective Activity of Aqueous and Hydroethanolic Extracts of Trema guineensis Leaves (Ulmaceae) against Gentamicin-Induced Nephrotoxicity in Rats. International Journal of Biochemistry Research \& Review, 15, 1-10. https://doi.org/10.9734/IJBCRR/2016/30539

[3] Hoenig, M.P. and Zeidel, M.L. (2014) Homeostasis, the Milieu Interieur, and the Wisdom of the Nephron. Clinical Journal of the American Society of Nephrology, 9 , 1272. https://doi.org/10.2215/CJN.08860813

[4] Mahipal, P. and Pawar, R.S. (2017) Nephroprotective Effect of Murraya koenigii on Cyclophosphamide Induced Nephrotoxicity in Rats. Asian Pacific Journal of Tropical Medicine, 10, 808-812. https://doi.org/10.1016/j.apjtm.2017.08.005

[5] Azab, A.E., Fetouh, F.A. and Albasha, M.O. (2014) Nephroprotective Effects of Curcumin, Rosemary and Propolis against Gentamicin Induced Toxicity in Guinea Pigs: Morphological and Biochemical Study. American Journal of Clinical and EX- 
perimental Medicine, 2, 28-35. https://doi.org/10.1016/j.apjtm.2017.08.005

[6] Porter, G.A. and Bennett, W.M. (1981) Nephrotoxic Acute Renal Failure Due to Common Drugs. American Journal of Physiology, 241, 252-256.

[7] Sundararajan, R., Bharampuram, A. and Koduru, R. (2014) A Review on Phyto-Constituents for Nephroprotective Activity. Pharm, 5, 160-182.

[8] Singh, N.P. and Prakash, A. (2011) Nephrotoxic Potential of Herbal Drugs. JIMSA, 24, 79-81.

[9] Srivastava, A.K., Kaushik, D., Shrivastava, A.K. and Lal, V.K. (2017) Nephroprotective Ethno-Medicinal Action of Selected Indian Medicinal Plants. Der Pharmacia Sinica, 8, 11-24.

[10] Adelman, R.D., Spangler, W.L., Beasom, F., Ishizaki, G. and Conzelman, G.M. (1981) Frusemide Enhancement of Neltimicin Nephrotoxicity in Dogs. Journal of Antimicrobial Chemotherapy, 7, 431-440. https://doi.org/10.1093/jac/7.4.431

[11] Paller, M.S. (1990) Drug Induced Nephropathies. Medical Clinics of North America, 74, 909-917. https://doi.org/10.1016/S0025-7125(16)30525-9

[12] Lakshmi, M.S., Reddy, U.K. and Rani, S.R.K.S. (2012) A Review on Medicinal Plants for Nephroprotective Activity. Asian Journal of Pharmaceutical and Clinical Research, 5, 8-14.

[13] Prior, R. and Cao, G. (1999) Antioxidant Capacity and Polyphone Compounds of Teas. PSEBM, 220, 255-261. https://doi.org/10.1046/j.1525-1373.1999.d01-44.x

[14] Robinson, E., Maxwell, S. and Thorpe, G. (1997) An Investigation of Antioxidant Activity of Black Tea, using Enhanced Chemiluminescence. Free Radical Research, 26, 291-300.

[15] EBSCO, CAM (2007) Review Board: Conditions: Atherosclerosis and Heart Disease Prevention. 4.

[16] Albasha, M.O. and Azab, A.E. (2014) Effect of Cadmium on the Liver and Amelioration by Aqueous Extracts of Fenugreek Seeds, Rosemary, and Cinnamon in Guinea Pigs: Histological and Biochemical Study. The Journal of Cell Biology, 2, 34-44. https://doi.org/10.11648/j.cb.20140202.11

[17] Al-Mamary, M., Al-Meeri, A. and Al-Habori, M. (2002) Antioxidant Activities and Total Phenolics of Different Types of Honey. Nutrition Research, 22, 1041-1047. https://doi.org/10.1016/S0271-5317(02)00406-2

[18] Ho, C., Ferrara, T., Chen, Q., Rosen, R. and Huang, M. (1994) Phytochemicals in Teas and Rosemary and Their Cancer Preventive Properties in: Food Phytochemicals for Cancer Prevention. American Chemical Society of Washington, 1, 2-19. https://doi.org/10.1021/bk-1994-0547.ch001

[19] Fetouh, F.A. and Azab, A.E. (2014) Ameliorating Effects of Curcumin and Propolis against the Reproductive Toxicity of Gentamicin in Adult Male Guinea Pigs: Quantitative Analysis and Morphological Study. American Journal of Life Sciences, 2, 138-149. https://doi.org/10.11648/j.ajls.20140203.13

[20] Marquele, F.D., Di Mambro, V.M., Georgetti, S.R., Casagrande, R., Valim, Y.M.L. and Fonseca, M.J.V. (2005) Assessment of the Antioxidant Activities of Brazilian Extracts of Propolis Alone and in Topical Pharmaceutical Formulation. Journal of Pharmaceutical and Biomedical Analysis, 39, 455-462. https://doi.org/10.1016/j.jpba.2005.04.004

[21] Handral, G.K., Pandith, A. and Shruthi, S.D. (2012) A Review on Murraya koenigii: Multipotential Medicinal Plant. Asian Journal of Pharmaceutical and Clinical Research, 5, 5-14. 
[22] Alhawari, S. (1986) Medical Plants as Food and Medicine. Saudi Arabia J, 21, 70-71.

[23] Heeba, G.H. and Abd-Elghany, M.I. (2010) Effect of Combined Administration of Ginger (Zingiber Officinale Roscoe) and Atorvastatin on the Liver of Rats. Phytomedicine, 17, 1076-1081. https://doi.org/10.1016/j.phymed.2010.04.007

[24] Yokozawa, T., Kim, Y.A., Kim, H.Y., Lee, Y.A. and Nonaka, G. (2007) Protective Effect of Persimmon Peel Polyphenol against High Glucose-Induced Oxidative Stress in LLC-PK1 Cells. Food and Chemical Toxicology, 45, 1979-1987. https://doi.org/10.1016/j.fct.2007.04.018

[25] Vaya, R.K., Sharma, A., Singhvi, I.J. and Agarwal, D.K. (2017) Nephroprotective Pants: A Review. Journal of Bioscience and Technology, 8, 801-812.

[26] Adeneye, A.A. and Benebo, A.S. (2008) Protective Effect of the Aqueous Leaf and Seed Extract of Phyllanthus amarus on Gentamicinand Acetaminophen-Induced Nephrotoxic Rats. Journal of Ethnopharmacology, 118, 318-323. https://doi.org/10.1016/j.jep.2008.04.025

[27] Nandave, M., Ojha, S.K., Joshi, S., Kumari, S. and Arya, D.S. (2009) Moringa oleifera Leaf Extract Prevents Isoproterenol-Induced Myocardial Damage in Rats: Evidence for an Antioxidant, Antiperoxidative, and Cardioprotective Intervention. Journal of Medicinal Food, 12, 47-55. https://doi.org/10.1089/jmf.2007.0563

[28] Abdollahi, M., Larijani, B., Rahimi, R. and Salari, P. (2005) Role of Oxidative Stress in Osteoporosis. Therapy, 2, 787-796. https://doi.org/10.2217/14750708.2.5.787

[29] Rajaratnam, M., Prystupa, A., Lachowska-Kotowska, P., Załuska, W. and Filip, R. (2014) Herbal Medicine for Treatment and Prevention of Liver Diseases. JPCCR, 8 , 55-60.

[30] Joe, B., Vijaykumar, M. and Lokesh, B.R. (2004) Biological Properties of Curcumin-Cellular and Molecular Mechanisms of Action. Critical Reviews in Food Science and Nutrition, 44, 97-111. https://doi.org/10.1080/10408690490424702

[31] Tirkey, N., Kaur, G., Vij, G. and Chopra, K. (2005) Curcumin a Diferuloylmethane, Attenuates Cyclosporine Induced Renal Dysfunction and Oxidative Stress in Rat Kidneys. Journal of Biosciences, 22, 233-246.

[32] Venkatesan, N., Punithavathi, D. and Arumugan, V. (2000) Curcumin Prevents Adriamycin Nephrotoxicity in Rats. British Journal of Pharmacology, 12, 231-234. https://doi.org/10.1038/sj.bjp.0703067

[33] Manikanadan, R., Beulaja, M., Thiagarajan, R., Priyadarsini, A., Saravanan, R. and Arumugam, M. (2011) Ameliorative Effects of Curcumin against Renal Injuries Mediated by Inducible Nitric Oxide Synthase and Nuclear Factor Kappa B during Gentamicin-Induced Toxicity in Wister Rats. European Journal of Pharmacology, 670, 578-585. https://doi.org/10.1016/j.ejphar.2011.08.037

[34] Biswas, S.K., Mc Clure, D., Jimenez, L.A., Megson, I.L. and Rahman, I. (2005) Curcumin Induces Glutathione Biosynthesis and Inhibit NF-Kappa B Activation and Interleukin-8 Release in Alveolar Epithelial Cells. Mechanism of Free Radical Scavenging Activity. Antioxidants \& Redox Signaling, 7, 32-41. https://doi.org/10.1089/ars.2005.7.32

[35] Flammang, A.M., Cifone, M.A., Ereson, G.L. and Stankowskci, L.F. (2004) Genotoxicity Testing of Fenugreek Extract. Food and Chemical Toxicology, 42, 205-208. https://doi.org/10.1016/j.fct.2004.07.003

[36] Basch, E., Ulbricht, C., Kuo, G., Szapary, P. and Smith, M. (2003) Therapeutic Application of Fenugreek. Alternative Medicine Review, 8, 20-27.

[37] Djeridane, A., Yousfi, M., Nadjemi, B., Boutassouma, D., Stocker, P. and Vidal, N. 
(2006) Antioxidant Activity of Some Algerian Medicinal Plants Extracts Containing Phenolic Compounds. Food Chemistry, 97, 654-660. https://doi.org/10.1016/j.foodchem.2005.04.028

[38] Blank, I., Lin, J., Devaud, S., Fumeaux, R. and Fay, L.B. (1997) The Principal Flavor Components of Fenugreek (Trigonella foenum-graceum L.). In: Risch, S.J. and Ho, C.T., Eds., Spices: Flavor Chemistry and Antioxidant Properties, American Chemical Society, ACS Symposium Series, 660, Washington DC, 12-28.

[39] Shitaw, K.N. (2015) Studies on the Levels of Fluoride in Selected Spices Cultivated and Consumed in Ethiopia. Master of Science in Analytical Chemistry, Department of Chemistry, College of Natural Sciences, Addis Ababa University.

[40] Rohini, R.M., Nayeem, M. and Das, A.K. (2008) Diuretic Effect of Trigonella foenum graecum Seed Extracts. The Internet Journal of Alternative Medicine, 6, 1-4.

[41] Schrier, R.W., Arroyo, V., Bernardi, M., Bernardi, M., Epstein, M., Henriksen, J.H. and Rodes, J. (1988) Peripheral Arterial Vasodilation Hypothesis: A Proposal for the Initiation of Renal Sodium and Water Retention in Cirrhosis. Hepatology, 8, 1151-1157. https://doi.org/10.1002/hep.1840080532

[42] El-Tawil, G.A. (2009) Effect of Fenugreek (Trigonella foenumgraecum) Supplementation on Radiation-Induced Oxidative Stress in Liver and Kidney of Rats. Journal of Radiation Research and Applied Sciences, 2, 19-30.

[43] Al-Atwi, L.F. (2010) Clinical Evaluation for the Diuretic Effect of the Alcoholic Extract of Trigonella faenumgracum Seeds (Fenugreek) on Rabbits. Kufa Journal for Veterinary Medical Sciences, 1, 116-121.

[44] El-Nawasany, S.A.El., Shalaby, S.I., Badria, F.A.E., Magraby, G.M. and Gupta, N. (2017) Diuretic Effect of Fenugreek (Trigonella foenumgraecum Linn) in Cirrhotic Ascitic Patients. Journal of Pharmacognosy and Phytochemistry, 6, 185-189.

[45] Mirunalini, S., Arulmozhi, V. and Arulmozhi, T. (2010) Curative Effect of Garlic on Alcoholic Liver Diseased Patients. Jordan Journal of Biological Sciences, 3, 147-152.

[46] Bongiorno, P.B., Fratellone, P.M. and Fratellone, P. (2008) Potential Health Benefits of Garlic Allium sativum, A Narrative Review. Journal of Complementary and Integrative Medicine, 5, 1-24. https://doi.org/10.2202/1553-3840.1084

[47] Agarwal, K.C. (1996) Therapeutic Actions of Garlic Constituents. Medicinal Research Reviews, 16, 111-125. https://doi.org/10.1002/(SICI)1098-1128(199601)16:1<111::AID-MED4>3.0.CO;2-5

[48] Block, E., Ahmed, S., Jain, M.K., Crecely, R.W., Apitz-Castro, R. and Cruz, M.R. (1984) Ajoene a Potent Antithrombotic Agent from Garlic. Journal of the American Chemical Society, 106, 8295-8296. https://doi.org/10.1021/ja00338a049

[49] Divya, B.J., Suman, B., kumar, L.L.,Venkataswamy, M., Eswari, B. and Thyagaraju, K. (2017) The Role of Allium sativum (garlic) in Various Diseases and Its Health Benefits: A Comprehensive Review. International Journal of Advanced Research, 5, 592-602. https://doi.org/10.21474/IJAR01/5094

[50] Josling, P.A. (2005) The Heart of Garlic Nature's Aid to Healing the Human Body. HEC Publishing, Chicago, 20.

[51] Gebreyohannes, G. and Gebreyohannes, M. (2013) Medicinal Values of Garlic: A Review. International Journal of Medical Sciences, 5, 401-408.

[52] Zaidi, S.K., Ansari, S.A., Ashraf, G.M., Jafri, M.A., Tabrez, S. and Banu, N. (2015) Reno-Protective Effect of Garlic Extract against Immobilization Stress Induced Changes in Rats. Asian Pacific Journal of Tropical Biomedicine, 5, 364-369. https://doi.org/10.1016/S2221-1691(15)30370-1 
[53] Rai, S.K., Sharma, M. and Tiwari, M. (2009) Inhibitory Effect of Novel Diallyldisulfide Analogs on HMG-CoA Reductase Expression in Hypercholesterolemic Rats: CREB as a Potential Upstream Target. Life Sciences, 85, 211-219. https://doi.org/10.1016/j.lfs.2009.05.020

[54] Asdaq, S.M. and Inamdar, M.N. (2010) Potential of Garlic and Its Active Constituent, S-allyl Cysteine, as Antihypertensive and Cardioprotective in Presence of Captopril. Phytomed, 17, 1016-1026. https://doi.org/10.1016/j.phymed.2010.07.012

[55] Ried, K., Toben, C. and Fakler, P. (2013) Effect of Garlic on Serum Lipids: An Updated Meta-Analysis. Nutrition Reviews, 71, 282-299. https://doi.org/10.1111/nure.12012

[56] Banerjee, S.K., Maulik, M., Manchanda, S.C., Dinda, A.K., Das, T.K. and Maulik, S.K. (2001) Garlic-Induced Alteration in Rat Liver and Kidney Morphology and Associated Changes in Endogenous Antioxidant Status. Food and Chemical Toxicology, 39, 793-797. https://doi.org/10.1016/S0278-6915(01)00018-7

[57] Abdel-Naim, A.B., Khalifaa, A.E. and Ahmed, S.H. (2002) Protective Effects of Garlic Oil against Liver Damage Induced by Combined Administration of Ethanol and $\mathrm{CCL}_{4}$ in Rats. The Egyptian Journal of Hospital Medicine, 6, 27-36.

[58] Hussein, J.S., Oraby, F.S. and El-Shafey, N. (2007) Antihepatotoxic Effect of Garlic and Onion Oils on Ethanol-Induced Liver Injury in Rats. Journal of Applied Sciences Research, 3, 1527-1533.

[59] El-Khayat, Z., Rasheed, W., Ramzy, T., Hussein, J., Agaiby, M., Morsy, S., Morsy, F. and Shaffie, N. (2010) Protective Effect of Garlic Oil against Liver Injury in Experimental Animals. Journal of Medicinal Plants Research, 4, 2359-2369.

[60] Abirami, N. and Jagadeeswari, R. (2006) Amelioration of Mercuric Chloride Induced Nephrotoxicity and Oxidative Stress by Garlic Extract. Ancient Science of Life, 26, 73-77.

[61] Horie, T., Awuzu, S., Itajura, Y. and Fuwa, T. (1992) Identified Diallyl Polysulfides from an Aged Garlic Extract Which Protects the Membrances from Lipid Peroxidation. Planta Medica, 52, 468-469. https://doi.org/10.1055/s-2006-961517

[62] Rani, B., Singh, U. and Maheshwari, R.K. (2013) Natural Antioxidants and Their Intrinsic Worth for Wellbeing. Global Journal Medical Research, 13, 54-69.

[63] Shiju, T.M., Rajesh, N.G. and Viswanathan, P. (2013) Renoprotective Effect of Aged Garlic Extract in Streptozotocin-Induced Diabetic Rats. Indian Journal of Pharmacology, 45, 18-23. https://doi.org/10.4103/0253-7613.106429

[64] Rafieian Kopaei, M., Baradaran, A., Merrikhi, A., Nematbakhsh, M., Madihi, Y. and Nasri, H. (2013) Efficacy of Co-Administration of Garlic Extract and Metformin for Prevention of Gentamicin-Renal Toxicity in Wistar Rats: A Biochemical Study. International Journal of Preventive Medicine, 4, 258-264.

[65] Wu, N., Greene, M. and Oderda, G. (2013) Patient Characteristics, Antidiabetic Medication Use, and Glycemic Control in Diabetic Nursing Home Residents with Moderate to Severe Chronic Kidney Disease. Value Health, 16, A174.

https://doi.org/10.1016/j.jval.2013.03.873

[66] Mima, A. (2013) Diabetic Nephropathy: Protective Factors and a New Therapeutic Paradigm. Journal of Diabetes and Its Complications, 27, 526-530. https://doi.org/10.1016/j.jdiacomp.2013.03.003

[67] Nasri, H. (2013) Renoprotective Effects of Garlic. Journal of Renal Injury Prevention, 2, 27-28.

[68] Lopez, M.G., Sanchez-Mendoza, I.R. and Ochoa-Alejo, N. (1999) Comparative 
Study of Volatile Components and Fatty Acids of Plants and in Vitro Cultures of Parsley Petroselinum crispum (Mill) nym ex hill. Journal of Agricultural and Food Chemistry, 47, 3292-3296. https://doi.org/10.1021/jf981159m

[69] Awe, E.O. and Banjoko, S.O. (2013) Biochemical and Haematological Assessment of Toxic Effects of the Leaf Ethanol Extract of Petroselinum crispum (Mill) Nyman ex A.W. Hill (Parsley) in Rats. BMC Complementary and Alternative Medicine, 13, 75. https://doi.org/10.1186/1472-6882-13-75

[70] Darias, V., Martin-Herrera, D., Abdalla, S. and Fuente, D. (2001) Plant Used in Urinary Pathologies in the Canary Island. Pharmaceutical Biology, 39, 170-180. https://doi.org/10.1076/phbi.39.3.170.5937

[71] Kreydiyyeh, S.I. and Usta, J. (2002) Diuretic Effect and Mechanism of Action of Parsley. Journal of Ethnopharmacology, 79, 353-359.

https://doi.org/10.1016/S0378-8741(01)00408-1

[72] Parsley and Informed Farmers. http://www.informedfarmers.com

[73] Farzaei, M.H., Abbasabadi, Z., Ardekani, M.R.S., Rahimi, R. and Farzaei, F. (2013) Parsley: A Review of Ethnopharmacology, Phytochemistry and Biological Activities. Journal of Traditional Chinese Medicine, 33, 815-826. https://doi.org/10.1016/S0254-6272(14)60018-2

[74] Jouad, H., Haloui, M., Rhiouani, H., El Hilaly, J. and Eddouks, M. (2001) Ethnobotanical Survey of Medicinal Plants Used for the Treatment of Diabetes, Cardiac and Renal Diseases in the North Centre Region of Morocco (Fez-Boulemane). Journal of Ethnopharmacology, 77, 175-182. https://doi.org/10.1016/S0378-8741(01)00289-6

[75] Ozsoy-Sacan, O., Yanardag, R., Orak, H., Ozgey, Y., Yarat, A. and Tunali, T. (2006) Effects of Parsley (Petroselinum crispum) Extract versus Glibornuride on the Liver of Streptozotocin Induced Diabetic Rats. Journal of Ethnopharmacology, 104, 175-181. https://doi.org/10.1016/j.jep.2005.08.069

[76] Ojala, T., Remes, S., Haansuu, P., Vuorela, H., Hiltunen, R., Haahtela, K. and Vuorela, P. (2000) Antimicrobial Activity of Some Coumarin Containing Herbal Plants Growing in Finland. Journal of Ethnopharmacology, 73, 299-305. https://doi.org/10.1016/S0378-8741(00)00279-8

[77] Wong, P.Y. and Kitts, D.D. (2006) Studies on the Dual Antioxidant and Antibacterial Properties of Parsley and Cilantro Extracts. Food Chemistry, 97, 505-515. https://doi.org/10.1016/j.foodchem.2005.05.031

[78] Maodaa, S.N., Allam, A.A., Ajarem, J., Abdel-Maksoud, M.A., Al-Basher, G.I. and Wang, Z.Y. (2016) Effect of Parsley (Petroselinum crispum, Apiaceae) Juice against Cadmium Neurotoxicity in Albino Mice (Mus musculus). Behavioral and Brain Functions, 12, 6. https://doi.org/10.1016/j.foodchem.2005.05.031

[79] Vora, S.R., Patil, R.B. and Pillai, M. (2012) Oxidative Stress Associated Alterations in Lysosomal Enzymes and Modulatory Effect of Petroselinum crispum (Mill) Nyman Ex. A.W. Hill Leaf Extract on Mouse Brain. American Journal of Scientific Research, 7, 64-68.

[80] Soliman, H.A., Eltablawy, N.A. and Hamed, M.S. (2015) The Ameliorative Effect of Petroselinum crispum (parsley) on Some Diabetes Complications. Journal of Medicinal Plants Studies, 3, 92-100.

[81] Caunii, A., Cuciureanu, R., Miklosne, A.Z., Tonea, E. and Giuchici, C. (2010) Chemical Composition of Common Leafy Vegetables. Studia Universitatis "Vasile Goldiş”. Seria Ştiințele Vieții, 20, 45-48.

[82] Yoshikawa, M., Uemura, T., Shimoda, H., Kishi, A., Kawahara, Y. and Mastuda, H. (2000) Medicinal Food Stuff XVIII. Phytoestrogens from Aerial Part of Petroseli- 
nium crispum Mill, and Structures of 6'-Acetylopin and a New Monoterpene Glycoside. Chemical and Pharmaceutical Bulletin, 48, 1039-1044. https://doi.org/10.1248/cpb.48.1039

[83] Popovic, D., Kaurinovic, B., Jakovljvic, V., Mimica-Dukic, N. and Bursac, M. (2007) Effect of Petroselinium crispum Extracts on Some Biochemical Parameters of Oxidase Stress in Mice Treated with $\mathrm{CCL}_{4}$. Phytotherapy Research, 7, 531-537.

[84] Zaynoun, S., Abi-Ali, L., Tenekjian, K. and Karban, A. (1985) The Bergapten Content of Garden Parsley and Its Significance in Causing Cutaneous Photosenstization. Clinical and Experimental Dermatology, 10, 328-331. https://doi.org/10.1248/cpb.48.1039

[85] Manderfield, M.M., Schafer, H.W., Davidson, P.M. and Zottola, E.A. (1997) Isolation and Identification of Antimicrobial Furocoumarins from Parsley. Journal of Food Protection, 60, 72-77. https://doi.org/10.4315/0362-028X-60.1.72

[86] Zhang, H., Chen, F., Wang, X. and Yao, H.-Y. (2006) Evaluation of Antioxidant Activity of Parsley (Petroselinum crispum) Essential Oil and Identification of Its Antioxidant Constituents. Food Research International, 39, 833-839.

https://doi.org/10.1016/j.foodres.2006.03.007

[87] Mahmood, S., Hussain, S. and Malik, F. (2014) Critique of Medicinal Conspicuousness of Parsley Petroselinum crispum, A Culinary Herb of Mediterranean Region. Pakistan Journal of Pharmaceutical Sciences, 27, 193-202.

[88] Blazovics, A., Lemberkovics, E., Petri, G., Szoke, E., Kery, A. and Fejes, S. (2000) Free Radical Scavenging and Membrane Protective Effects of Methanol Extracted Fractions of Parsley. Acta Alimentaria, 29, 81-87. https://doi.org/10.1556/AAlim.29.2000.1.8

[89] Peterson, S., Lampe, J.W., Bammler, T.K., Gross-Steinmeyer, K. and Eaton, D.L. (2006) Apiaceous Vegetable Constituents Inhibit Human Cytochrome P-450 1A2 (hCYP1A2) Activity and hCYP1A2-Mediated Mutagenicity of Aflatoxin B1. Food and Chemical Toxicology, 44, 1474-1484. https://doi.org/10.1016/j.fct.2006.04.010

[90] Potapovich, A.I. and Kostyuk, V.A. (2003) Comparative Study of Antioxidant Properties and Cytoprotective Activity of Flavonoids. Biochem, 68, 514-519.

[91] Kinoshita, T., Lepp, Z., Kawai, Y., Terao, J. and Chuman, H. (2006) An Integrated Database of Flavonoids. Biofactors, 26, 179-188. https://doi.org/10.1002/biof.5520260303

[92] Lin, C.M., Chen, C.S., Chen, C.T., Liang, Y.C. and Lin, J.K. (2002) Molecular Modeling of Flavonoids That Inhibits XO. Biochemical and Biophysical Research Communications, 294, 167-172. https://doi.org/10.1016/S0006-291X(02)00442-4

[93] Hall, I.H., Scoville, J.P., Reynolds, D.J., Simlot, R. and Duncan, P. (1990) Substituted Cyclic Imides as Potential Anti-Gout Agents. Life Sciences, 46, 1923-1927. https://doi.org/10.1016/0024-3205(90)90507-N

[94] Rashwan, N.M. (2012) Biological Study on the Effect of Arginine and Parsley on Renal Toxicity in Rats. World Journal of Medical Sciences, 7, 264-269.

[95] Campanella, L., Bonanni, A., Favero, G. and Tomassetti, M. (2003) Determination of Antioxidant Properties of Aromatic Herbs, Olives and Fresh Fruit using an Enzymatic Sensor. Analytical and Bioanalytical Chemistry, 375, 1011-1016. https://doi.org/10.1007/s00216-003-1825-1

[96] Fejes, S.Z., Blazovics, A., Lemberkovics, E., Petri, G., Szoke, E. and Kery, A. (2000) Free Radical Scavenging and Membrane Protective Effects of Methanol Extracts from Anthriscus cerefolium (Hoffm) L. and Petroselinum crispum (Mill) Nym. Ex A. W. Hill. Phytotherapy Research, 14, 362-365. 
https://doi.org/10.1002/1099-1573(200008)14:5<362::AID-PTR554>3.0.CO;2-G

[97] Jassim, A.M. (2013) Protective Effect of Petroselinum crispum (parsley) Extract on Histopathological Changes in Liver, Kidney and Pancreas Induced by Sodium Valproate-in Male Rats. Kufa Journal for Veterinary Medical Sciences, 4, 20-27.

[98] Dorman, H.J., Lantto, T.A., Raasmaja, A. and Hiltunen, R. (2011) Antioxidant, Pro-Oxidant and Cytotoxic Properties of Parsley. Food \& Function, 2, 328-337. https://doi.org/10.1039/c1fo10027k

[99] Papay, Z.F., Kosa, A., Boldizsar, I., Ruszkai, A., Balogh, E. and Antal, I. (2012) Pharmaceutical and Formulation Aspects of Petroselinum crispum Extract. Acta Pharmaceutica Hungarica, 82, 3-14.

[100] Saeidi, J., Bozorgi, H., Zendehdel, A. and Mehrzad, J. (2012) Therapeutic Effects of Aqueous Extracts of Petroselinum sativum on Ethylene Glycol-Induced Kidney Calculi in Rats. Urology Journal, 9, 361-366.

[101] Afzal, M., Khan, N.A., Ghufran, A., Iqbal, A. and Inamuddin, M. (2004) Diuretic and Nephroprotective Effect of Jawarish Zarooni Sada, a Polyherbal Formulation. Ethnopharmacol, 91, 219-223. https://doi.org/10.1016/j.jep.2003.12.029

[102] Shalaby, M.A. and Hammoda, A.A. (2014) Evaluation of Nephroprotective and Diuretic Effects of Parsley and Turmeric Herbs on Gentamicin Nephrotoxic Rats. World Journal of Pharmaceutical Sciences, 3, 1729-1744.

[103] Fejes, S., Kery, A., Blazovics, A., Lugasi, A., Lemberkovics, E. and Petri, G. (1998) Investigation of the in Vitro Antioxidant Effect of Petroselinum crispum. Acta Pharmaceutica Hungarica, 68, 150-156.

[104] Elkhamisy, A.E. (2015) Protective Effect of Parsley Leaves and Turmeric Roots Extracts against Gentamicin Induced Nephrotoxicity in Male Rats. World Journal of Dairy \& Food Sciences, 10, 1-8.

[105] Mahmoud, N.Y., Salem, Z.A. and El-Moslemany, A.M. (2015) Nephroprotective and Antioxidant Effects of Parsley Plant Parts against Gentamicin-Induced Nephrotoxicity in Rats. Academy Journal Nutrition, 4, 113-122.

[106] Bennani-Kabchi, N., Fdhil, H., El-Bouayadi, F., Amarti, A., Saidi, M. and Marquie, G. (1999) Effects of Olea europea Var. oleaster and Cryptotaenia japonica Leaves in Hypercholesterolemic Insulin-Resistant Sand Rats. 5eme Congres de la Societe Mediterraneenne de Pharmacol Clin Therap, 54, 717-723.

[107] Khalil, A.F., Elkatry, H.O. and El Mehairy, H.F. (2015) Protective Effect of Peppermint and Parsley Leaves Oils against Hepatotoxicity on Experimental Rats. Annals of Agricultural Sciences, 60, 353-359. https://doi.org/10.1016/j.aoas.2015.11.004

[108] Unver, A., Arslan, D., Ozcan, M. and Akbulut, M. (2009) Phenolic Content and Antioxidant Activity of Some Spices. World Applied Sciences Journal, 6, 373-377.

[109] Ali, Z.Y. (2012) Biochemical Evaluation of Some Natural Products against Toxicity Induced by Anti-Tubercular Drugs in Rats. New York Science Journal, 5, 69-80.

[110] Murray, M.T. (1995) The Healing Power of Herbs: The Enlightened Person's Guide to the Wonders of Medicinal Plants. Prima Pub., Rocklin, Vol. 14, 410.

[111] Rita, P. and Animesh, D.K. (2011) An Updated Overview on Peppermint (Mentha piperita L). IRJP, 2, 1-10.

[112] Rastogi, R.P. and Mehrotra, B.N. (1993) Compendium of Indian Medicinal Plants. CDRI, Lucknow and Publications and Information Directorate, New Delhi.

[113] Sharma, A., Sharma, M.K. and Kumar, M. (2007) Protective Effect of Mentha piperita against Arsenic-Induced Toxicity in Liver of Swiss Albino Mice. Basic \& Clinical Pharmacology \& Toxicology, 100, 249-257. 
https://doi.org/10.1111/j.1742-7843.2006.00030.x

[114] Baliga, M.S. and Rao, S. (2010) Radioprotective Potential of Mint: A Brief Review. Journal of Cancer Research and Therapeutics, 6, 255-262. https://doi.org/10.4103/0973-1482.73336

[115] Zarfeshany, A., Asgary, S. and Javanmard, S.H. (2014) Potent Health Effects of Pomegranate. Advanced Biomedical Research, 3, 1-8.

[116] Ercisli, S., Gadze, J., Agar, G., Yildirim, N. and Hizarci, Y. (2011) Genetic Relationships among Wild Pomegranate (Punica granatum) Genotypes from Coruh Valley in Turkey. Genetics and Molecular Research, 10, 459-464. https://doi.org/10.4238/vol10-1gmr1155

[117] Fawole, O.A. and Opara, U.L. (2013) Developmental Changes in Maturity Indices of Pomegranate Fruit: A Descriptive Review. Scienta Horticulture, 159, 152-161. https://doi.org/10.1016/j.scienta.2013.05.016

[118] Li, Y., Guo, C., Yang, J., Wei, J., Xu, J. and Cheng, S. (2006) Evaluation of Antioxidant Properties of Pomegranate Peel Extract in Comparison with Pomegranate Pulp Extract. Food Chemistry, 96, 254-260. https://doi.org/10.1016/j.foodchem.2005.02.033

[119] Faria, A., Monteiro, R., Mateus, N., Azevedo, I. and Calhau, C. (2007) Effect of Pomegranate (Punica granatum) Juice Intake on Hepatic Oxidative Stress. European Journal of Nutrition, 46, 271-278. https://doi.org/10.1007/s00394-007-0661-Z

[120] El Habibi, E.M. (2013) Renoprotective Effects of Punica granatum (Pomegranate) against Adenine-Induced Chronic Renal Failure in Male Rats. Life Sciences Journals, 10, 2059-2069.

[121] Huang, S., Zhang, C.P., Wang, K., Li, G.Q. and HuRecent, F.L. (2014) Advances in the Chemical Composition of Propolis. Molecules, 19, 19610-19632.

https://doi.org/10.3390/molecules191219610

[122] Singh, A.P., Singh, A.J. and Singh, N. (2011) Pharmacological Investigations of Punica granatum in Glycerol-Induced Acute Renal Failure in Rats. Indian Journal of Pharmacology, 43, 551-556. https://doi.org/10.4103/0253-7613.84971

[123] Albasha, M.O. and Azab, A.E. (2016) Hepatorenal Protective Effects of Pomegranate (Punica granatum) Juice against Nicotine Induced Toxicity in Guinea Pigs. Journal of Advances in Biology \& Biotechnology, 5, 1-13. https://doi.org/10.9734/JABB/2016/21996

[124] Calin-Sanchez, A. and Carbonell, B.A.A. (2012) The Pomegranate Fruit Grown in Spain Antioxidant Punicalagin in Pomegranate Juice and Pomegranate Extract, for Functional Diet of the Future. Granatum Plus: Miguel Hernandez University. Food Technology Department, 79.

[125] Cerada, B., Llorach, R., Ceron, J.J., Espin, J.C. and Tomas Barberan, F.A. (2003) Evaluation of the Bioavailability and Metabolism in the Rat of Punicalagin, an Antioxidant Polyphenol from Pomegranate Juice. European Journal of Nutrition, 42, 18-28. https://doi.org/10.1007/s00394-003-0396-4

[126] Taygi, S., Singh, A., Bhardwaj, P., Sahu, S., Yadav, P. and Kori, M.L. (2012) Punicalgins-A Large Polypheno Compounds Found in Pomegranates: A Therapeutic Review. Journal of Plant Sciences, 5, 45-49.

[127] Al Olayan, E.M., El Khadragy, M.F., Metwally, D.M. and Abdel Moneim, A.E. (2014) Protective Effects of Pomegranate (Punica granatum) Juice on Testes against $\mathrm{CCL}_{4}$ Intoxication in Rats. BMC Complementary and Alternative Medicine, 164, 1-9.

[128] Ali, N.A.M. and Saeed, S.Z. (2012) Nephro-Protective Effect of Punica granatum in 
Gentamicin Induced Nephrotoxicity in Rats. Medical Journal of Babylon, 9, 220-228.

[129] Ahmed, M.M. and Ali, S.E. (2010) Protective Effect of Pomegranate Peel Ethanol Extract against Ferric Nitrilotriacetate Induced Renal Oxidative Damage in Rats. Journal of Cell and Molecular Biology, 8, 35-43.

[130] Aviram, M., Dornfeld, L., Kaplan, M., Coleman, R., Gaitini, D., Nitecki, S., Hofman, A., Rosenblat, M., Volkova, N., Presser, D., Attias, J., Hayek, T. and Fuhrman, B. (2002) Pomegranate Juice Flavonoids Inhibit Low Density Lipoprotein Oxidation and Cardiovascular Diseases: Studies in Atherosclerotic Mice and in Humans. Drugs under Experimental and Clinical Research, 28, 49-62.

[131] Yasoubi, P., Barzegar, M., Sahari, M.A. and Azizi, M.H. (2007) Total Phenolic Contents and Antioxidant Activity of Pomegranate (Punica granatum L.) Peel Extracts. Journal of Agricultural Science and Technology, 9, 35-42.

[132] Afaq, F., Saleem, M., Krueger, C.G., Reed, J.D. and Mukhtar, H. (2005) Anthocyanin and Hydrolyzable Tannin Rich Pomegranate Fruit Extract Modulates MAPK and NF-kappa B Pathways and Inhibits Skin Tumorigenesis in CD-1 Mice. International Journal of Cancer, 113, 423-433. https://doi.org/10.1002/ijc.20587

[133] Lansky, E.P. and Newman, R.A. (2007) Punica granatum (pomegranate) and Its Potential for the Prevention and Treatment of Cancer and Inflammation. Journal of Ethnopharmacology, 109, 177-206. https://doi.org/10.1016/j.jep.2006.09.006

[134] Turk, G., Sonmez, M., Aydin, M., Yuce, A., Gur, S., Yuksel, M., Aksu, E.H. and Aksoy, H. (2008) Effects of Pomegranate Juice Consumption on Sperm Quality, Spermatogenic Cell Density, Antioxidant Activity and Testosterone Level in Male Rats. Clinical Nutrition, 27, 289-296. https://doi.org/10.1016/j.clnu.2007.12.006

[135] Huang, T.H., Yang, Q., Harada, M., Li, G.Q., Yamahara, J., Roufogalis, B.D., et al. (2005) Pomegranate Flower Extract Diminishes Cardiac Fibrosis in Zucker Diabetic Fatty Rats: Modulation of Cardiac Endothelin-1 and Nuclear Factor-Kappa B Pathways. Journal of Cardiovascular Pharmacology, 46, 856-862. https://doi.org/10.1097/01.fjc.0000190489.85058.7e

[136] Valdivielso, J.M., Lopez Novoa, J.M., Eleno, N. and Barriocanal, P.F. (2000) Role of Glomerular Nitric Oxide in Glycerol-Induced Acute Renal Failure. Canadian Journal of Physiology and Pharmacology, 78, 476-482. https://doi.org/10.1139/y00-012

[137] Aydogdu, N., Atmaca, G., Yalcin, O., Taskiran, R., Tastekin, E. and Kaymak, K. (2006) Protective Effects of L-Carnitine on Myoglobinuric Acute Renal Failure in Rats. Clinical and Experimental Pharmacology and Physiology, 33, 119-124. https://doi.org/10.1111/j.1440-1681.2006.04336.x

[138] Tugcu, V., Kemahli, E., Ozbek, E., Arinci, Y.V., Uhri, M., Erturkuner, P., Metin, G., Seckin, I., Karaca, C., Ipekoglu, N., Altug, T., Cekmen, M.B. and Tasci, A.I. (2008) Protective Effect of a Potent Antioxidant, Pomegranate Juice, in the Kidney of Rats with Nephrolithiasis Induced by Ethylene Glycol. Journal of Endourology, 22, 2723-2731. https://doi.org/10.1089/end.2008.0357

[139] Li, Y.J., Lin, J.L., Yang, C.W. and Yu, C.C. (2005) Acute Renal Failure Induced by a Brazilian Variety of Propolis. American Journal of Kidney Diseases, 46, e125-e129.

[140] Gunduz, C., Biray, C., Kosova, B., Yilmaz, B., Eroglu, Z., Sahin, F., Omay, S.B. and Cogulu, O. (2005) Evaluation of Manisa propolis Effect on Leukemia Cell Line by Telomerase Activity. Leukemia Research, 29, 1343-1346. https://doi.org/10.1016/j.leukres.2005.04.010

[141] Ozguner, F., Bardak, Y. and Comlekci, S. (2006) Protective Effects of Melatonin and Caffeic Acid Phenethyl Ester against Retinal Oxidative Stress in Long-Term Use of 
Mobile Phone. A Comparative Study. Molecular and Cellular Biochemistry, 282, 83-88. https://doi.org/10.1007/s11010-006-1267-0

[142] Fokt, H., Pereira, A., Ferreira, A.M., Cunha, A. and Aguiar, C. (2010) How Do Bees Prevent Hive Infections? The Antimicrobial Properties of Propolis. Current Research, Technology and Education Topics in Applied Microbiology and Microbial Biotechnology. Mendez A. (Ed.), 481-493.

[143] Ali, H.S. and Rasool, B.K.A. (2011) Propolis Buccal Paste in Treatment of Aphthous Ulceration: Formulation and Clinical Evaluation. Asian Journal of Pharmaceutical and Clinical Research, 4, 29-33.

[144] Papotti, G., Bertelli, D., Bortolotti, L. and Plessi, M. (2012) Chemical and Functional Characterization of Italian Propolis Obtained by Different Harvesting Methods. Journal of Agricultural and Food Chemistry, 60, 2852-2862. https://doi.org/10.1021/jf205179d

[145] Silici, S. and Kutluca, S. (2005) Chemical Composition and Antibacterial Activity of Propolis Collected by Three Different Races of Honey Bees in the Same Region. Journal of Ethnopharmacology, 99, 69-73. https://doi.org/10.1016/j.jep.2005.01.046

[146] Komericki, P. and Kranker, B. (2009) Maculopapular Exanthem from Propolis: Case Report and Review of Systemic Cutaneous and Noncutaneous Reactions. Contact Dermatitis, 61, 353-355. https://doi.org/10.1111/j.1600-0536.2009.01642.x

[147] Park, E.K., Kim, S.H. and Park, S.S. (1996) Anti-Inflammatory Activity of Propolis. Archives of Pharmacal Research, 19, 337-341. https://doi.org/10.1007/BF02976375

[148] Paintz, M. and Metzner, J. (1979) Zur lokalanasthetischen Wirkung von Propolis und einigen Inhaltsstoffen. Pharm, 34, 839-841.

[149] Ahn, M., Kumazawa, S., Hamasaka, T., Bang, K. and Nakayama, T. (2004) Antioxidant Activity and Constituents of Propolis Collected in Various Areas of Korea. Journal of Agricultural and Food Chemistry, 52, 7286-7292. https://doi.org/10.1021/jf048726s

[150] Orsolic, N., Knezevic, A.H., Sver, L., Terzic, S. and Basic, I. (2004) Immuno-Modulatory and Antimetastatic Action of Propolis and Related Polyphenolic Compounds. Journal of Ethnopharmacology, 94, 307-315. https://doi.org/10.1016/j.jep.2004.06.006

[151] Park, E.H. and Kahng, J.H. (1999) Suppressive Effects of Propolis in Rats Adjuvant Arthritis. Archives of Pharmacal Research, 22, 554-558. https://doi.org/10.1007/BF02975325

[152] Bankova, V.S., De Castro, S.L. and Marcucci, M.C. (2000) Propolis: Recent Advances in Chemistry and Plant Origin. Apidologie, 31, 3-15. https://doi.org/10.1051/apido:2000102

[153] Azab, E.A., Algridi, M.A. and Lashkham, N.M. (2015) Hypolipidemic and Antiatherogenic Effects of Aqueous Extract of Libyan propolis in Lead Acetate Intoxicated Male Albino Mice. IJSR, 4, 1060-1068.

[154] Abd El-Rahman, S.S. (2010) West-Libyan Propolis and Rosemary Have Synergistic Anti-Tumor Effect against 12-Otetradecanoylphorbol 13-Acetate-Induced Skin Tumor in BULB/C Mice Previously Initiated with 7,12-Dimethy lbenz[a] anthracene. Basic and Applied Pathology, 3, 46-51. https://doi.org/10.1111/j.1755-9294.2010.01079.x

[155] Salem, T.A., Bassiouny, K., Kabel, M., Elsayed, I.H. and El-Kenaway, A.E. (2010) The Protective Role of Propolis on Gentamicin Induced Nephrotoxicity in Rats. Sci J Fac Sci Minufia Univ, 24, 1-13.

[156] Sun, F., Hayami, S., Haruna, S., Ogiri, Y., Tanaka, K. and Yamada, Y. (2000) In Vi- 
vo Antioxidative Activity of Propolis Evaluated by the Interaction with Vitamin $\mathrm{C}$ and $\mathrm{E}$ and the Level of Lipid Hydroperoxides in Rats. Journal of Agricultural and Food Chemistry, 48, 1462-1465. https://doi.org/10.1021/jf990594t

[157] Osman, I.H. and Tantaway, A.A. (2013) Antioxidant Activity and Protective Effects of Commercial Propolis on Gentamicin Induced Nephrotoxicity in Rabbits in Vitro Study. Turkish Journal of Biochemistry, 38, 409-415. https://doi.org/10.5505/tjb.2013.29200

[158] Atta, A.H., Nasr, S.M., Mouneir, S.M., Abdel-Aziem, S.H. and Nassar, S.A. (2014) Egyptian Propolis Alleviates Gentamicin-Induced Nephrotoxicity in Rats. Journal of Advances in Chemistry, 6, 1109-1119.

[159] Aboulgasem, G.J.A., Azab, A.E. and Almaky, M.M. (2015) Sodium Nitrite Induced Biochemical Alterations in the Blood Serum and Its Amelioration by Aqueous Extract of Libyan Propolis in Guinea Pigs. International Journal of Science and Research, 4, 1040-1048.

[160] Usami, E., Kusano, G., Takayose, T., Wachi, H. and Seyama, Y. (2004) Assessment of Antioxidant Activity of Natural Compounds by Water and Lipid-Soluble Antioxidant Factor. Yakugaku Zasshi, 124, 847-850.

https://doi.org/10.1248/yakushi.124.847

[161] Ferrali, M., Signorini, C. and Caciotti, B. (1997) Protection against Oxidative Damage of Erythrocytes Membrane by the Flavinoid Quercetin and Its Relation to Iron Chelatingactivity. FEBS Letters, 416, 123-129. https://doi.org/10.1016/S0014-5793(97)01182-4

[162] Kanbura, M., Eraslan, G. and Silici, S. (2009) Antioxidant Effect of Propolis against Exposure to Propetamphos in Rats. Ecotoxicology and Environmental Safety, 72, 909-915. https://doi.org/10.1016/j.ecoenv.2007.12.018

[163] Al-Attar, A.M., Alrobai, A.A. and Almalki, D.A. (2017) Protective Effect of Olive and Juniper Leaves Extracts on Nephrotoxicity Induced by Thioacetamide in Male Mice. Saudi Journal of Biological Sciences, 24, 15-22. https://doi.org/10.1016/j.sjbs.2015.08.013

[164] Tabera, J., Guinda, A., Ruiz-Rodriguez, A., Senorans, F.J., Ibáñez, E., Albi, T. and Reglero, G. (2004) Countercurrent Supercritical Fluid Extraction and Fractionation of High-Added Value Compounds from a Hexane Extract of Olive Leaves. Journal of Agricultural and Food Chemistry, 52, 4774-4779. https://doi.org/10.1021/jf049881+

[165] Al-Sowayan, N.S. and Mousa, H.M. (2014) Ameliorative Effect of Olive Leaf Extract on $\mathrm{CCL}_{4}$-Induced Nephrotoxicity in Rats. Life Sciences Journals, 11, 238-242.

[166] Silva, S., Gomes, L., Leitao, F., Coelho, A.V. and Boas, L.V. (2006) Phenolic Compounds and Antioxidant Activity of Olea europaea L. Fruits and Leaves. Food Science and Technology International, 12, 385-395.

https://doi.org/10.1177/1082013206070166

[167] Dekanski, D., Janicijevic-Hudomal, S., Tadic, V., Markovic, G., Arsic, I. and Mitrovic, D.M. (2009) Phytochemical Analysis and Gastroprotective Activity of an Olive Leaf Extract. Journal of the Serbian Chemical Society, 74, 367-377. https://doi.org/10.2298/JSC0904367D

[168] Jemai, H., El Feki, A. and Sayadi, S. (2009) Antidiabetic and Antioxidant Effects of Hydroxytyrosol and Oleuropein from Olive Leaves in Alloxan-Diabetic Rats. Journal of Agricultural and Food Chemistry, 57, 8798-8804. https://doi.org/10.1021/jf901280r

[169] Khayyal, M.T., El-Ghazaly, M.A., Abdallah, D.M., Nassar, N.N., Okpanyi, S.N. and 
Kreuter, M.H. (2002) Blood Pressure Lowering Effect of an Olive Leaf Extract (Olea europaea) in L-NAME Induced Hypertension in Rats. Arzneimittel Forschung, 52, 797-802.

[170] Wang, L., Geng, C., Jiang, L., Gong, G., Liu, D., Yoshimura, H. and Zhong, L. (2008) The Anti-Atherosclerotic Effect of Olive Leaf Extract Is Related to Suppressed Inflammatory Response in Rabbits with Experimental Atherosclerosis. European Journal of Nutrition, 47, 235-243. https://doi.org/10.1007/s00394-008-0717-8

[171] Hamdi, H.K. and Castellon, R. (2005) Oleuropein, a Non-Toxic Olive Iridoid, Is an Anti-Tumor Agent and Cytoskeleton Disruptor. Biochemical and Biophysical Research Communications, 334, 769-778. https://doi.org/10.1016/j.bbrc.2005.06.161

[172] Pieroni, A., Heimler, D., Pieters, L., Van Poel, B. and Vlietinck, A.J. (1996) In Vitro Anti Complementary Activity of Flavonoids from Olive (Olea europaea L.) Leaves. Pharm, 51, 765-768.

[173] Eidi, A., Eidi, M. and Darzi, R. (2009) Antidiabetic Effect of Olea europaea L. in Normal and Diabetic Rats. Phytotherapy Research, 23, 347-350. https://doi.org/10.1002/ptr.2629

[174] Benavente-Garcia, O., Castillo, J., Lorente, J., Ortuno, A. and DelRio, J.A. (2000) Antioxidant Activity of Phenolics Extracted from Olea europaea L. Leaves. Food Chemistry, 68, 457-462. https://doi.org/10.1002/ptr.2629

[175] Ashour, S.E.S. (2011) Hematological and Biochemical Studies on the Effect of Some Natural Antioxidants Pre-Injection in Irradiated Rats. PhD Thesis, Fac. Agri., Benha Univ.

[176] Zari, T.A. and Al-Attar, A.M. (2011) Therapeutic Effects of Olive Leaves Extract on Rats Treated with a Sublethal Concentration of Carbendazim. European Review for Medical and Pharmacological Sciences, 15, 413-426.

[177] Tavafi, M., Ahmadvand, H. and Toolabi, P. (2012) Inhibitory Effect of Olive Leaf Extract on Gentamicin-Induced Nephrotoxicity in Rats. Iranian Journal of Kidney Diseases, 6, 25-32.

[178] Visioli, F., Galli, C., Plasmati, E., Viappiani, S., Hernandez, A., Colombo, C. and Sala, A. (2000) Olive Phenol Hydroxytyrosol Prevents Passive Smoking-Induced Oxidative Stress. Circulation, 102, 2169-2171. https://doi.org/10.1161/01.CIR.102.18.2169

[179] Nekooeian, A., Dehghani, G., Mostafavi, H. and Khalili, A. (2011) The Effect of Hydroalcoholic Extract of Olive Leaves on Blood Pressure in Rat Model of Two-Kidney, One-Clip Goldblatt Hypertension. Iranian Cardiovascular Research Journal, 5, 1-6.

[180] Bawazir, A.E. (2011) Chronic Effect of Olive Oil on Some Neurotransmitter Contents in Different Brain Regions and Physiological, Histological Structure of Liver and Kidney of Male Albino Rats. World Journal of Neuroscience, 1, 31-37. https://doi.org/10.4236/wjns.2011.13005

[181] Al-Attar, A.M. and Abu Zeid, I.M. (2013) Effect of Tea (Camellia sinensis) and Olive (Olea europaea L.) Leaves Extracts on Male Mice Exposed to Diazinon. BioMed Research International, 2013, Article ID: 461415. https://doi.org/10.1155/2013/461415

[182] Al-Jubury, N.O.H. (2013) Effects of Olive Leaves Extract on Urea, Uric Acid and Creatinine Concentrations in Serum of Heat Stressed Male Rabbits. Journal of Was- 
sit for Science \& Medicine, 6, 225-236.

[183] Rafighdoost, H., Tavafi, M., Rasoulian, B., Ahmadvand, H., Mahmodi, M. and Rashidi Pour, M. (2013) Effect of Olive Leaf Extract Ininhibition of Renal Ischemia-Reperfusion Injuries in Rat. Anatomical Sciences Journal, 10, 160-165.

[184] Zoair, M.A. (2014) A Possible Antioxidant Effect of Olive Leaf Extraction in Diabetic Rats. Global Journal of Scientific Researches, 2, 165-170.

[185] Jemai, H., El Feki, A., Feriani, A. and Sayadi, S. (2015) Histopathological and Oxidative Features in Alloxan-Induced Diabetic Rats' Kidneys and the Preventive Effects of the 3,4-Dihydroxy-Phenylethanol. International Journal of Development Research, 5, 4371-4375.

[186] El-Sherif, N.M. and Issa, N.M. (2015) Protective Effect of Rosemary (Rosmarinus offi cinalis) Extract on Naphthalene Induced Nephrotoxicity in Adult Male Albino Rat. Journal of Interdisciplinary Histopathology, 3, 24-32. https://doi.org/10.5455/jihp.20150213020636

[187] Sakr, S.A. and Lamfon, H.A. (2012) Protective Effect of Rosemary (Rosmarinus officinalis) Leaves Extracts on $\mathrm{CCL}_{4}$-Induced Nephrotoxicity in Albino Rats. Life Sciences Journals, 9, 779-785.

[188] Aruoma, O., Halliwell, B., Aeschbach, R. and Loligers, J. (1992) Antioxidant and Pro-Oxidant Properties of Active Rosemary Constituents: Carnosol and Carnosic Acid. Xenobiotica, 22, 257-268. https://doi.org/10.3109/00498259209046624

[189] Moreno, S., Scheyer, T., Romano, C.S. and Vojnov, A.A. (2006) Antioxidant and Antimicrobial Activities of Rosemary Extract Linked to Their Polyphenol Composition. Free Radical Research, 40, 223-231. https://doi.org/10.1080/10715760500473834

[190] Kadri, A., Zarai, Z., Ben Chobba, I., Bekir, A., Gharsallah, N., Damak, M. and Gdoura, R. (2011) Chemical Constituents and Antioxidant Properties of Rosmarinus officinalis L. Essential Oil Cultivated from South-Western Tunisia. Journal of Medicinal Plants Research, 5, 5999-6004.

[191] Nusier, M.K., Bataineh, H.N. and Daradkah, H.M. (2007) Adverse Effects of Rosemary (Rosmarinus officinalis L.) on Reproductive Function in Adult Male Rats. Experimental Biology and Medicine, 232, 809-813.

[192] Zohrabi, M., Ashtiyani, S.C., Hajihashemi, S., Hassanpoor, A. and Hosseini, N. (2012) The Study of $24 \mathrm{H}$ Post Treatment Effects of the Aqueous Extract of Rosmarinus officinalis after Renal Ischemia/Reperfusion in Rat. Journal of Physiology and Pathophysiology, 3, 12-19.

[193] Tavafi, M. and Ahmadvand, H. (2011) Effect of Rosmarinic Acid on Inhibition of Gentamicin Induced Nephrotoxicity in Rats. Tissue and Cell, 43, 392-397. https://doi.org/10.1016/j.tice.2011.09.001

[194] Abdelkader, M.A., El-Sammad, N.M. and Taha, H. (2012) The Protective Role of Rosemary (Rosmarinus Officinalis) in Lead Acetate Induced Toxicity in Rats. Journal of Applied Sciences Research, 8, 3071-3082.

[195] Mannaa, F.A., Abdalla, M.S., Abdel-Wahhab, K.G. and EL-Kassaby, M.I. (2013) Effect of Some Nutraceutical Agents on Aluminum-Induced Functional Neurotoxicity in Senile Rats: I. Effect of Rosemary Aqueous Extract and Docosahexaenoic Acid. Journal of Applied Sciences Research, 9, 2322-2334.

[196] Abd El Kader, M.A., El-Sammad, N.M. and Taha, H. (2012) The Protective Role of Rosemary (Rosmarinus officinalis) in Lead Acetate Induced Toxicity in Rats. Jour- 
nal of Applied Sciences Research, 8, 3071-3082.

[197] Azab, A.E. and Albasha, M.O. (2015) Simultaneous Administration of Aqueous Extract of Rosmarinus officinal with Nicotine Resulted in Prevention of Induced Hepatorenal Toxicity in Guinea Pigs. American Journal of Bioscience and Bioengineering, 3, 80-86. https://doi.org/10.11648/j.bio.20150305.20

[198] Erkan, N., Ayranci, G. and Ayranci, E. (2008) Antioxidant Activities of Rosemary (Rosmarinus officinalis L.) Extract, Blackseed (Nigella sativa L.) Essential Oil, Carnosic Acid, Rosmarinic Acid and Sesamol. Food Chemistry, 110, 76-82.

https://doi.org/10.1016/j.foodchem.2008.01.058

[199] Mulinacci, N., Innocenti, M., Bellumori, M., Giaccherini, C., Martini, V. and Michelozzi, M. (2011) Storage Method, Drying Processes and Extraction Procedures Strongly Affect the Phenolic Fraction of Rosemary Leaves: An HPLC/DAD/MS Study. Talanta, 85, 167-176. https://doi.org/10.1016/j.talanta.2011.03.050

[200] Marzieh, Z., Saeed, C., Saeed, H. and Akbar, H. (2012) The Study of 24 h Post Treatment Effects of the Aqueous Extract of Rosmarinus officinalis after Renal Ischemia/Reperfusion in Rat. Journal of Physics, 2, 12-19.

[201] Perez-Fons, L., Aranda, F.J., Guillen, J., Villalain, J. and Micol, V. (2006) Rosemary (Rosmarinus officinalis) Diterpenes Affect Lipid Polymorphism and Fluidity in Phospholipids Membranes. Archives of Biochemistry and Biophysics, 453, 224-236. https://doi.org/10.1016/j.abb.2006.07.004

[202] Snakar, D., Ramakrishna, R.M., Sambandam, G. and Pugallendi, V. (2006) Effect of Sesame Oil on Diuretics or $B$ Blockers in Modulation of Blood Pressure, Anthropometry, Lipid Profile and Redox Status. The Yale Journal of Biology and Medicine, 79, 19.

[203] Choi, A.M., Lee, S.B., Cho, S.H., Hwang, I., Hur, C.G. and Suh, M.C. (2008) Isolation and Characterization of Multiple Abundant Lipid Transfer Protein Isoforms in Developing Sesame Seeds. Plant Physiology and Biochemistry, 46, 127. https://doi.org/10.1016/j.plaphy.2007.10.003

[204] Yamashita, K., Iizuka, Y., Imai, T. and Namiki, M. (1995) Sesame Seed and Its Lignans Produce Marked Enhancement of Vitamin E Activity in Rats Fed a Low Alpha-Tocopherol Diet. Lipid, 30, 1019-1028. https://doi.org/10.1007/BF02536287

[205] Azab, A.E., El-Dakhly, A.T., Alrawi, Q.K. and Albasha, M.O. (2015) Protective Effects of Sesame Oil against Lead Acetate Induced Haemato-Biochemical Toxicity in Albino Mice. International Journal of Science and Research, 4, 2053-2063.

[206] Kandangath, R.A., Ajay, P., Farhath, K. and Amarinder, S.B. (2010) Nutritional, Medicinal and Industrial Uses of Sesame (Sesamum indicum L.) Seeds-An Overview. Agriculturae Conspectus Scientificus, 75, 159-168.

[207] Si-Hyung, P., Su-Noh, R., Young-Min, B., HoCheol, K., Simon, J.E. and KwanSu, K. (2010) Antioxidant Components as Potential Neuroprotective Agents in Sesame (Sesamum indicum L.). Food Reviews International, 26, 103-121. https://doi.org/10.1080/87559120903564464

[208] Ikeda, S., Kagaya, M., Kobayashi, K., Tohyama, T., Kiso, Y. and Higuchi, N. (2003) Dietary Sesame Lignans Decrease Lipid Peroxidation in Rats Fed Docosahexaenoic Acid. Journal of Nutritional Science and Vitaminology (Tokyo), 49, 270-276. https://doi.org/10.3177/jnsv.49.270

[209] Bhuvaneswari, P. and Krishnakumari, S. (2012) Nephroprotective Effects of Ethanolic Extract of Sesamum indicum Seeds in Streptozotocin Induced Diabetic Male 
Albino Rats. International Journal of Green Pharmacy, 6, 330-335.

https://doi.org/10.4103/0973-8258.108249

[210] Iqpal, M., Rezazadeh, H., Ansar, S. and Athar, M. (1998) Alpha $\alpha$-Tocopherol (Vitamin E) Ameliorates Ferric Nitro-Triacetate (Fe-NTA) Dependent Renal Proliferative Response and Toxicity: Diminution of Oxidatice Stress. Human \& Experimental Toxicology, 17, 163-171. https://doi.org/10.4103/0973-8258.108249 